\title{
Eclogitic metagabbro from the Lanzada Window, eastern Central Alps: confirmation of subduction beneath the Malenco Unit
}

\author{
Giles T.R. Droop ${ }^{1}$ and Déborah Chavrit \\ School of Earth, Atmospheric \& Environmental Sciences, \\ University of Manchester, \\ Oxford Road, \\ Manchester M13 9PL, UK. \\ ${ }^{1}$ Corresponding author: e-mail: Giles.Droop@manchester.ac.uk \\ Running title: Eclogite from the Lanzada Window
}




\begin{abstract}
Epidote-rich eclogitic metagabbro forms a small body within the Lanzada Window, upper Val Malenco, where it is associated with serpentinites and supracrustal rocks of the Lanzada - Santa Anna Zone (LSZ), which lies structurally beneath the Malenco unit. Conventional garnet-clinopyroxene geothermometry and garnet-clinopyroxene-phengite geobarometry indicate that the peak-metamorphic mineral assemblage (garnet + omphacite + epidote + phengite + titanite + apatite + pyrite) equilibrated at ca. $2.0 \mathrm{GPa}$ and $525^{\circ} \mathrm{C}$. The bulk composition is Ca-rich (wollastonite-normative), suggesting that the rock underwent $\mathrm{Ca}$ metasomatism prior to high- $P$ metamorphism. The presence of eclogite within the LSZ strengthens the correlation of the LSZ with the blueschist-bearing Avers Bündnerschiefer, and confirms the former existence of a southerly-dipping subduction zone beneath the Malenco unit.
\end{abstract}

Key words: epidote-eclogite; Lanzada - Santa Anna Zone; Ca-metasomatism; subduction; Piemont-Ligurian ocean.

\title{
1 Introduction
}

It has long been recognised that there is a close connection between rocks of highpressure, low-temperature facies, such as blueschists and low-/medium- $T$ eclogites, and subduction zones (e.g. Ernst 1973), to the extent that the existence of such rocks is generally taken as good evidence for the site of a former subduction zone (e.g. Evans and Brown 1986; Carswell 1990). The purpose of this paper is to report on a chance find of an eclogite in the Lanzada - Santa Anna Zone, a tectonic unit of the eastern Central Alps from which no high- $P$ 
rocks have previously been recorded. Because of the link between high- $P$ rocks and subduction, the find is significant as it helps to constrain the tectonic evolution of the Alpine orogen.

\subsection{Geotectonic background}

According to the models of Froitzheim et al. (1996), Schmid et al. (2004, 2008) and Handy et al. (2010), the Alpine mountain belt is the product of two orogenic episodes: (i) the closure, in Cretaceous times, of the Meliata ocean between the northern and southern parts of the Apulian plate (Alcapia and Adria, respectively), and (ii) the sequential closure, in the Tertiary, of the Piemont-Liguria and Valais branches of Alpine Tethys, between the Apulian and European plates. The two branches of Alpine Tethys were separated by the Briançonnais continental mass (Frisch 1979), thought to be the eastern extension of the Iberian continent. In the Central Alps, Tertiary continental convergence and collision was accommodated by southeasterly subduction and/or underthrusting of the Alpine-Tethyan oceanic lithosphere and of slices of the adjacent continental margins, including the Briançonnais. The resulting nappe stack (Fig. 1) includes basement nappes of European provenance (e.g. the Adula nappe), remnants of the Valais basin (e.g. the Chiavenna ophiolite and Rhenodanubian flysch), basement nappes from the Briançonnais domain (e.g. the Tambo and Suretta nappes), ophiolitic remnants of the Piemont-Ligurian ocean (e.g. the Avers Bündnerschiefer, Platta nappe and Forno portion of the Malenco unit), and Austroalpine basement nappes from the north-western margin of the Apulian plate (e.g. the Err and Bernina nappes and higher Austroalpine nappes) (Schmid et al. 2004). Most of the continental basement nappes are structurally overlain by thin and highly deformed cover sequences of Permo-Mesozoic passive-margin or oceanic sedimentary rocks. 
The palaeogeographical origin of the lowest Austroalpine continental basement nappes, the Margna and Sella nappes ('Ma' and 'Se', respectively, in Fig. 1), is somewhat controversial. Hermann et al. (1997) consider them to represent the distal part of the Apulian plate, but Frisch (1979), Froitzheim et al. (1996) and Schmid et al. (2004) argue that they represent a micro-continent between north-western (Avers-Forno) and south-eastern (Platta) portions of the Piemont-Ligurian ocean generated during mid-Jurassic rifting. The NW part of the Malenco unit ('M-F' in Fig. 1), which preserves an original transition from continental lower crust to mantle, directly underlay part of the Margna nappe prior to rifting (Trommsdorff et al. 1993; Müntener and Hermann 1996; Hermann et al. 1997). The Malenco unit and its incorporated lower crust show widespread evidence of exhumation to the sea floor during rifting (Müntener et al. 2000).

The present disposition of the aforementioned units in the eastern Central Alps (Fig. 1) is the product of a complex interplay of rifting (Mohn et al. 2010, 2011), imbrication, exhumation and repeated plastic deformation, culminating in intrusion by granitoid magmas of the Bergell complex at ca. 33-26 Ma (von Blanckenburg 1992; Hansmann 1996; Oberli et al. 2004) and back-thrusting of the nappe stack along the Periadriatic Line between ca. 28-18 Ma (Schmid et al. 1996).

\subsection{Alpine metamorphism in the Central Alps}

In the Central Alps, relict Alpine high- $P$ mineral assemblages appear to be confined to units underlying the Austroalpine nappes (the 'Penninic' units), but not all Penninic units preserve high- $P$ relics. Well preserved and intensively studied eclogite-facies rocks occur in the Adula and Cima Lunga nappes (e.g. O’Hara and Mercy 1966; Ernst 1977; Evans and Trommsdorff 1978; Heinrich 1986; Meyre et al. 1997; Nimis and Trommsdorff 2001; Dale and Holland 2003), but variably retrogressed eclogites also occur in Valais-derived ophiolitic 
associations in the Antrona zone and the Mergoscia and Orselina zones of the Southern Steep Belt (Colombi and Pfeifer 1986; Pfeifer et al 1991; Tóth et al. 2000; Brouwer et al. 2005). Trommsdorff (1990) and Brouwer et al. (2005) viewed this assemblage of high- $P$ units as a lithosphere-scale tectonic mélange and interpreted it as the product of a tectonic accretion channel that developed during convergence and collision along the Apulia-Europe plate boundary. Well constrained ages for the eclogitic metamorphism are mostly in the range $40-$ 35 Ma (Becker 1993; Gebauer 1996; Brouwer et al. 2005).

Lower-grade high- $P$ assemblages are preserved in the Valais-derived Bündnerschiefer of the Vals area (Wiederkehr et al. 2009) and Engadine Window (Goffé and Oberhänsli 1992; Bousquet et al. 1998), respectively, north and north-east of the area shown in Fig. 1. Relict blueschist-facies assemblages in these units developed at peak- $P$ conditions of $1.2-1.4 \mathrm{GPa}$ (Bousquet et al. 2002) at ca. 42 - $40 \mathrm{Ma}$ (Wiederkehr et al. 2009). These dates agree well with those from the eclogite-facies rocks further south and with them provide a tight constraint on the timing of the closure of the Valais basin.

Previously published reports of high- $P$ metamorphism in the Briançonnais- and Piemont-Liguria-derived Penninic units overlying the Adula nappe in the eastern Central Alps are confined to relict blueschist-facies assemblages in the Avers Bündnerschiefer (Oberhänsli 1978; Ring 1992) and the northern parts of the Suretta and Tambo nappes (Ring 1992; Nussbaum et al. 1998). Estimated peak- $P$ conditions for these units are as follows:- Avers: $350-400{ }^{\circ} \mathrm{C}, 0.9->1.2 \mathrm{GPa}$ (Ring 1992); Suretta: $380-420^{\circ} \mathrm{C}, 0.8->1.0 \mathrm{GPa}$ (Ring 1992), $400-450{ }^{\circ} \mathrm{C}, 1.0 \mathrm{GPa}$ (Nussbaum et al. 1998); Tambo: $400-480{ }^{\circ} \mathrm{C}, 0.8-1.0 \mathrm{GPa}$ (Ring 1992). Subduction of these units to greater depths in Eocene times (50-40 Ma) is implicit in the balanced cross-sections of Schmid (1996). In the Western Alps, the peak of ultra-high- $P$ metamorphism in the Piemont-Liguria-derived ophiolitic Lago di Cignana unit has been dated at $44 \mathrm{Ma}$ (Rubatto et al. 1998), in agreement with this timing. 
No high- $P$ mineral assemblages have been reported from the Malenco unit, or the Margna, Sella or Platta nappes. Rb/Sr mineral isochron ages of $c a .50-47 \mathrm{Ma}$ from pervasively deformed rocks from the Platta nappe and overlying Austroalpine basement have been interpreted by Bachmann et al. (2009) as dating the cessation of subduction along the northern margin of Apulia.

The dominant metamorphic imprint in the Central Alps west of the Bergell intrusive complex is the Tertiary Barrovian greenschist- to amphibolite-facies metamorphism centred on the Lepontine area (e.g. Frey and Ferreiro-Mählmann 1999). This metamorphism overprinted the high- $P$ assemblages to varying extents and post-dated collision-related nappe refolding (Wiederkehr et al. 2008), as testified by the smooth, concentric pattern of isograds transecting nappe boundaries (e.g. Thompson 1976; Trommsdorff 1980; Frey and FerreiroMählmann 1999). It developed as the result of thermal relaxation within the tectonically thickened nappe stack (e.g. Todd and Engi 1997; Wiederkehr et al. 2008; Berger et al. 2011), possibly augmented by additional mantle heat flow following slab break-off (von Blanckenburg and Davies 1995). In the sillimanite zone near Bellinzona, the thermal peak of metamorphism has been dated at ca. 33 Ma by Gebauer $(1996 ; 1999)$ but the data of Rubatto et al. (2009) indicate that temperatures high enough for anatexis persisted in these rocks until ca. 22 Ma. East of the Bergell, however, the effects of the Lepontine overprint are largely absent (Frey and Ferreiro-Mählmann 1999), and the regional metamorphism is at least partly of Cretaceous age, as documented by ${ }^{39} \mathrm{Ar}-{ }^{40} \mathrm{Ar}$ amphibole ages of $67-73 \mathrm{Ma}$ for the latest detected crystallisation in the Malenco unit (Villa et al. 2000).

\subsection{The Lanzada - Santa Anna Zone}

The Lanzada - Santa Anna Zone (LSZ) is an enigmatic assemblage of rocks of uncertain palaeogeographical origin structurally underlying the Malenco unit (Trommsdorff et 
al. 2005). With an outcrop area totalling $<6 \mathrm{~km}^{2}$ (Montrasio et al 2005), the LSZ is exposed in two small tectonic windows in Val Malenco, one (the Lanzada window) in the centre of the Malenco unit outcrop and the other (the Santa Anna window) near its southern boundary (Fig. 1). The outcrop pattern is controlled by the interference of two sets of upright folds related to back-folding (Trommsdorff et al. 2005). The LSZ, as defined by Trommsdorff et al. (2005), corresponds partly to the Lanzada-Scermendone Zone of Montrasio (1984), but the latter author identified a third window (Alpe Airale) west of the other two which is not included in the LSZ in the map of Montrasio et al. (2005).

The rocks of the LSZ include Permo-Mesozoic supracrustal rocks of pre-rift, passivemargin origin, such as quartzites, marbles and dolomites, as well as those of oceanic affinity, such as greenschists, calc-schists, ophicarbonates and Mn-rich schists (Trommsdorff et al. 2005). Also present are small bodies of serpentinite and metagabbro, interpreted as either olistoliths or tectonic slices (Montrasio 1984). The tectonic map of the Alps (Spicher 1980) shows an outcrop of orthogneiss in the centre of the Lanzada window and, although this does not appear on the map of Montrasio et al. (2005), we confirm the existence of an augen gneiss exposure $2 \mathrm{~km} \mathrm{NE}$ of the town of Lanzada at Swiss map coordinates 78941281 (latitude $46^{\circ}$ 16' 43" N; longitude 953' 52" E). Orthogneisses, interpreted as pre-Triassic crystalline basement, occur within the Alpe Airale window and are included in the LanzadaScermendone Zone by Montrasio (1984).

According to Trommsdorff et al. (2005), the LSZ may have been derived from the ocean-continent transition of the Briançonnais realm. On the basis of lithological similarities and tectonic position, Montrasio (1984) correlated the metasediments and ophiolitic rocks of the LSZ with the Avers Bündnerschiefer and the orthogneisses with the Suretta nappe. A similar lithological assemblage along the eastern and south-eastern margins of the Bergell complex (Fig. 1) has been confidently correlated with the Suretta nappe and its Avers cover 
(Gieré 1985; Trommsdorff et al. 2005). The possibility of the Suretta nappe outcropping within the Lanzada Window was also noted by Trümpy (1980).

The dominant metamorphism in the LSZ is of albite-epidote-amphibolite facies, with tremolite developed in marbles, rare garnet in pelites, and amphibole + epidote + chlorite + albite in metabasites (Montrasio 1984). The age of this metamorphism is unknown. The eclogitic metagabbro described in this paper is the first evidence of high- $P$ metamorphism in the LSZ and in the Malenco area as a whole.

\section{Field occurrence and petrography}

The eclogitic metagabbro outcrop is located on the southern flank of Monte Motta $c a$. $0.8 \mathrm{~km}$ NNE of Lanzada, at Swiss map coordinates 78821278 (latitude $46^{\circ} 16^{\prime} 33^{\prime \prime} \mathrm{N}$; longitude $\left.9^{\circ} 52^{\prime} 53^{\prime \prime} \mathrm{E}\right)$. It forms a small (ca. 2m-wide) exposure on the footpath that contours westwards from a W-closing hairpin bend in the Lanzada-Franscia road. It is closely associated with schistose serpentinites and greenschists that crop out along the SE side of a prominent band of marble which, according to the map of Montrasio et al. (2005), defines the NW margin of the Lanzada Window. Unfortunately, the field relations of the metagabbro body are unclear as its contact with the associated serpentinites and greenschists are not exposed. Nonetheless, the position of the metagabbro locality relative to the marble means that there is no doubt that it lies within the Lanzada Window, rather than within the Malenco Unit or along the boundary between the two.

The metagabbro is a medium-grained, weakly foliated L-S tectonite consisting mainly of omphacite and epidote with subordinate garnet. The omphacite and epidote each form irregular, nearly monomineralic aggregates, commonly measuring $c a .20 \times 10 \times 5 \mathrm{~mm}$ but locally up to $40 \times 20 \times 10 \mathrm{~mm}$. Within the aggregates, the omphacite and epidote prisms are 
imperfectly aligned parallel to the long axes of the aggregates. Assuming that the epidote and omphacite aggregates represent former plagioclase- and pyroxene-rich domains, the size of the aggregates implies that the gabbroic protolith was very coarse grained.

The full mineral assemblage of the metagabbro is garnet + omphacite + epidote + phengite + titanite + hornblende + albite + biotite + pyrite + apatite. Modal proportions based on a point-count of a thin-section (1000 points) are: Grt 6\%, Omp 52\%, Ep 35\%, Phe $<<1 \%$, Ttn 3\%, Hbl 1\%, Ab 1\%, Bt $<<1 \%$, Pyt $<<1 \%$, Ap $<<1 \%$ (abbreviations from Kretz, 1983). The small total mode of retrograde minerals (hornblende, albite and biotite) reflects the fact that, compared to many Alpine eclogites, the rock shows little post-eclogitic alteration.

The garnet forms irregular porphyroblasts up to $8 \mathrm{~mm}$ in diameter with abundant inclusions of titanite and epidote. Garnet rims are lobate and commonly intergrown with omphacite and epidote (Fig. 2a). Omphacite forms green prisms measuring up to $4 \times 1.5 \mathrm{~mm}$ but are more typically 1-2 mm long. The cores of many of the larger omphacites contain numerous dark, fluid-filled inclusions aligned parallel to the c-axes of their host crystals. Epidote prisms tend to be smaller than those of omphacite, measuring up to $2 \times 0.4 \mathrm{~mm}$, and better aligned. Most prisms are optically zoned with slightly higher-birefringence rims and contain rare fluid inclusions. Small amounts of yellow, highly birefringent epidote coexist with albite, hornblende and biotite in retrogressed domains, particularly close to garnet. Phengite is rare, forming either isolated crystals enclosed by omphacite, or irregular flakes, up to $0.8 \mathrm{~mm}$ across, surrounded by retrogressive biotite, albite and yellow epidote. Titanite is the only Ti-phase present and forms sub-/euhedral crystals up to $0.4 \mathrm{~mm}$ long. Scattered, randomly oriented euhedral hornblende prisms up to $6 \times 1 \mathrm{~mm}$ cut across the foliation defined by omphacite and epidote and locally contain relict inclusions of omphacite (Fig. 2b). Albite forms localised, irregular, interstitial or poikiloblastic grains replacing garnet and omphacite, and is usually associated with hornblende. 
On the basis of the textural relations, the peak-metamorphic mineral assemblage of the metagabbro is Grt + Omp + Ep + Phe + Ttn + Pyt + Ap.

The occurrence of titanite in the peak assemblage, rather than rutile, the more common Ti-phase of eclogites (Carswell 1990), is intriguing and may be due to the unusually Ca-rich bulk composition (see below).

\section{Mineral chemistry}

Minerals were analysed by wavelength-dispersive spectrometry using the Cameca SX100 electron-microprobe at the University of Manchester. Standards used were wollastonite $(\mathrm{Si}, \mathrm{Ca})$, rutile $(\mathrm{Ti})$, corundum $(\mathrm{Al})$, eskolaite $(\mathrm{Cr})$, fayalite $(\mathrm{Fe})$, tephroite $(\mathrm{Mn})$, periclase $(\mathrm{Mg})$, adularia $(\mathrm{K})$, and jadeite $(\mathrm{Na})$. Analyses were obtained at an accelerating voltage of $15 \mathrm{kV}$, beam diameter of $c a .1 \mu \mathrm{m}$, and count times of $20 \mathrm{~s}$ and $10 \mathrm{~s}$ on peaks and backgrounds, respectively. X-ray counts were processed using PAP software (Pouchou and Pichoir 1991). Representative analyses are listed in Table 1.

\subsection{Garnet}

Garnet formulae were calculated assuming $\Sigma\left(\mathrm{Al}, \mathrm{Cr}, \mathrm{Fe}^{3+}, \mathrm{Fe}^{2+}, \mathrm{Mn}, \mathrm{Mg}, \mathrm{Ca}\right)=5.00$

per formula unit (pfu). The analyses show small Si deficiencies (mean $\left.\mathrm{X}_{\mathrm{Si}}{ }^{\mathrm{IV}}=0.98\right)$, suggesting a small but finite amount of $\mathrm{Si}=4 \mathrm{H}$ substitution due to hydrogarnet component. Calculated $\mathrm{Fe}^{3+}$ contents scatter from zero to 0.035 pfu. Garnet porphyroblasts show relatively simple zoning profiles, with $\mathrm{Mn}$ and $\mathrm{Fe}$ decreasing, and $\mathrm{Mg}$ and $\mathrm{Ca}$ increasing from core to rim (Fig. 3). The lobate porphyroblast rim regions are compositionally fairly uniform compared to garnet interiors. Extreme compositions are $\operatorname{alm}_{61.0}$ py $_{4.6} \operatorname{grs}_{28.2} \mathrm{sps}_{4.5} \operatorname{adr}_{0.2}$ hy-gr 1.4 (core) and $\operatorname{alm}_{54.4}$ py$_{6.6} \operatorname{grs}_{33.3} \operatorname{sps}_{3.3} \operatorname{adr}_{0.2}$ hy-gr 2.2 (rim). 


\subsection{Omphacite}

Omphacite formulae were calculated assuming 4.00 cations per 6(O) (Droop 1987). Compositions are shown on the jadeite-acmite-augite diagram of Essene and Fyfe (1967) in Fig. 4. Almost all compositions plot within the omphacite field in this diagram. Individual crystals show no consistent zoning patterns, but there are distinct differences between the compositions of omphacites close to garnet and epidote and those of omphacites from the interiors of monomineralic aggregates (Fig. 4). The former have a mean composition of $\mathrm{jd}_{38}$ $\mathrm{acm}_{13} \operatorname{aug}_{49}$ and range from $28 \%-45 \% \mathrm{jd}$ and $9 \%-16 \%$ acm, closely resembling omphacites from many low- and medium-T eclogites (e.g. those of the Zermatt-Saas zone - Fig. 4). The mean $\mathrm{Mg} /\left(\mathrm{Mg}+\mathrm{Fe}^{2+}\right)$ value is 0.80 . In contrast, the crystals from the interiors of omphacite aggregates are consistently richer in 'augite' components and poorer in acmite and generally also in jadeite, having a mean composition of $\mathrm{jd}_{27} \mathrm{acm}_{06} \operatorname{aug}_{67}$ and mean $\mathrm{Mg} /\left(\mathrm{Mg}+\mathrm{Fe}^{2+}\right)$ value of 0.83 .

\subsection{Epidote}

Epidote formulae were calculated assuming all $\mathrm{Fe}$ to be $\mathrm{Fe}^{3+}$. Away from retrogressed areas, epidote cores show $\mathrm{Fe}^{3+} /\left(\mathrm{Al}+\mathrm{Fe}^{3+}\right)$ values ranging from 0.11 to 0.15 whilst rims show values ranging from 0.16 to 0.19 . The yellow retrogressive epidotes have $\mathrm{Fe}^{3+} /\left(\mathrm{Al}+\mathrm{Fe}^{3+}\right)$ values in the range $0.26-0.30$.

\subsection{Phengite}

Phengite formulae were calculated assuming all $\mathrm{Fe}$ to be $\mathrm{Fe}^{2+}$. Owing to the scarcity of phengite in the section, only two crystals were analysed, and we are forced to assume that their compositions are representative. The mean composition (based on four analyses) is 
approximately $\mathrm{K}_{0.84} \mathrm{Na}_{0.07} \mathrm{Mg}_{0.33} \mathrm{Fe}_{0.17} \mathrm{Ti}_{0.02} \mathrm{Al}_{2.28} \mathrm{Si}_{3.29} \mathrm{O}_{10}(\mathrm{OH})_{2}$, with $\mathrm{Mg} /\left(\mathrm{Mg}+\mathrm{Fe}^{2+}\right)$ and $\mathrm{Na} /(\mathrm{Na}+\mathrm{K})$ values of 0.65 and 0.08 , respectively.

\subsection{Titanite}

Titanite analyses show $\mathrm{Ca}$ and $\mathrm{Si}$ contents close to the ideal value of 1.00 per 5(O). $\mathrm{Al}$ contents range from 0.04 to $0.11 \mathrm{pfu}$ and are inversely correlated with $\mathrm{Ti}(0.91-0.96 \mathrm{pfu})$.

\subsection{Hornblende}

Hornblende formulae were calculated assuming $\Sigma(\mathrm{Si}, \mathrm{Ti}, \mathrm{Al}, \mathrm{Cr}, \mathrm{Fe}, \mathrm{Mg}, \mathrm{Mn})=13.00$ per 23(O) anhydrous (Droop 1987). With Ca contents of 1.47 to $1.55 \mathrm{pfu}$, these amphiboles are marginally subcalcic and plot close to the boundary between the magnesiohornblende and barroisite fields in the classification scheme of Leake et al. (1997). Si and Al contents are quite variable, ranging from 7.06 to 7.36 and 1.07 to $1.47 \mathrm{pfu}$, respectively, as are $\mathrm{Mg} /\left(\mathrm{Mg}+\mathrm{Fe}^{2+}\right)$ values $(0.69-0.76)$. Most of the variation is inter-crystalline, but within individual crystals there is slight zoning with rimwards increases in $\mathrm{Ca}$ and $\mathrm{Al}$ and decreases in $\mathrm{Si}, \mathrm{Na}$ and $\mathrm{Mg} /\left(\mathrm{Mg}+\mathrm{Fe}^{2+}\right)$. On the $100 \mathrm{Na} /(\mathrm{Na}+\mathrm{Ca})$ vs. $100 \mathrm{Al} /(\mathrm{Al}+\mathrm{Si})$ plot of Laird and Albee (1981), the hornblendes plot in the high-P field (Fig. 5) and, in this respect, resemble the retrograde $\mathrm{Ca}$ - and $\mathrm{NaCa}$-amphiboles of the Zermatt-Saas zone more closely than the $\mathrm{Ca}$ amphiboles of the overlying Malenco unit and Margna nappe.

\subsection{Albite}

Retrograde albite compositions are close to end-member (>98\% ab).

\section{Whole-rock geochemistry}


The bulk composition of the Lanzada metagabbro was obtained by X-ray fluorescence spectrometry (XRF), using the PANalytical ${ }^{\mathrm{TM}}$ Axios XRF spectrometer at the University of Manchester. Duplicate sample pellets were prepared from $100 \mathrm{~g}$ of powdered rock by mixing $12 \mathrm{~g}$ rock powder with $3 \mathrm{~g}$ wax binder. X-ray counts were processed using the $\mathrm{IQ}+$ program. The two analyses were the same, within error; mean major and trace element concentrations are given in Table 2. A crude estimate of the bulk $\mathrm{Fe}^{2+} / \mathrm{Fe}_{\text {tot }}$ of 0.46 (atomic) was obtained from mineral modes and compositions and used to compute an amended major-element analysis and CIPW weight norm (Table 2).

Compared that of Le Maitre's (1976) average gabbro (Table 2), the major-element analysis of the Lanzada metagabbro is characterised by low concentrations of $\mathrm{SiO}_{2}, \mathrm{MgO}$ and $\mathrm{K}_{2} \mathrm{O}$, very high $\mathrm{CaO}$, high $\mathrm{Na}_{2} \mathrm{O}$ and $\mathrm{MnO}$, and similar $\mathrm{TiO}_{2}, \mathrm{Al}_{2} \mathrm{O}_{3}, \mathrm{P}_{2} \mathrm{O}_{5}$ and total $\mathrm{Fe}$ oxides. Although the overall $\mathrm{Fe}$ oxide total is unremarkable, the high proportion of $\mathrm{Fe}_{2} \mathrm{O}_{3}$ is unusual; oxide-rich ferrogabbros commonly show this trait (as well as low $\mathrm{SiO}_{2}$ ) but are usually characterised by high total Fe oxides and correspondingly high $\mathrm{TiO}_{2}$, which is not the case here. The most striking feature of the metagabbro analysis is the very high $\mathrm{CaO}(\sim 18 \%)$ which is $c a .3 \sigma$ above that of Le Maitre's (1976) average gabbro. Coupled with modest $\mathrm{Al}_{2} \mathrm{O}_{3}$ and alkalies and low $\mathrm{SiO}_{2}$, this produces appreciable wollastonite and nepheline in the norm as well as much diopside (Table 2).

Without appealing to calcite or melilite in the protolith, the appearance of significant normative wollastonite cannot be explained in terms of compositional or modal variations among the 'usual' minerals of gabbros (olivine, pyroxenes, plagioclase, Fe,Ti-oxides). Instead, it implies that the protolith was subjected to Ca-metasomatism prior to metamorphism. Cametasomatism of basic igneous rocks in a variety of geological settings is well documented and includes (i) rodingite formation accompanying serpentinisation of peridotite (e.g. Coleman 1967; Honnorez and Kirst 1975; Wenner 1979; Austrheim and Prestvik 2008), (ii) 
epidosite formation during high- $T$ hydrothermal alteration of oceanic crust at ocean ridges (e.g. Bickle and Teagle 1992; Nehlig et al. 1994; Jowitt et al. 2012, Wang et al. 2012) and fore-arcs (e.g. Banerjee et al. 2000), and (iii) hydrothermal alteration of high-level dolerite and gabbro intrusions in a continental setting (e.g. Dickin and Jones 1983; Rose and Bird 1994). However, in the absence of the protolith composition, it is impossible to establish with certainty which, if any, of these types of alteration affected the Lanzada metagabbro, particularly as (i) they are likely to generate similar geochemical trends (e.g. decreasing $\mathrm{Na}_{2} \mathrm{O}$ and LILE), and (ii) the degree of metasomatic alteration was probably modest (as testified by e.g. the unexceptional $\mathrm{Na}_{2} \mathrm{O}$ content).

$\mathrm{Ca}$ enrichment is one of several types of metasomatism for which there is evidence in Alpine ophiolitic rocks (Widmer et al. 2000). As well as rodingitisation (Vuagnat 1967; Li et al. 2008; Zanoni et al. 2011) and epidotisation (Bowtell et al. 2007), metabasalts of the Zermatt-Saas zone collectively show evidence of spilitisation (Bearth and Stern 1971) and hydrothermal chloritisation (Martin and Tartarotti 1989; Widmer et al. 2000; Martin et al. 2008). On the $\mathrm{MgO}-\mathrm{CaO}-\mathrm{Na}_{2} \mathrm{O}$ plot of Widmer et al. (2000), which summarises the geochemical trends associated with these types of alteration, the Lanzada metagabbro plots in the part of the diagram characterised by rodingitisation and epidotisation (Fig. 6). However, it plots well to the high-Na side of the rodingitisation trend defined by the metarodingite data of Evans et al. (1981) and arguably matches the poorly defined epidotisation trend better (Fig. 6).

If the likelihood of metasomatism is accepted, there is little scope for using the geochemistry of the metagabbro to elucidate the tectonic setting of its protolith. One exception may be the use of the relatively immobile trace elements $\mathrm{Ti}, \mathrm{Nb}$ and $\mathrm{Y}$. On the $\mathrm{TiO}_{2}$ versus Y/Nb plot of Floyd and Winchester (1975), the Lanzada metagabbro plots within the field of tholeiitic basalts but in the area of overlap between continental and oceanic tholeiites (Fig. 7). However, acceptance of this result would require us to assume that the trace element 
concentrations were not modified by cumulus processes during crystallisation of the gabbro protolith, which is hard to justify.

\section{Thermobarometry}

The high variance of the Lanzada metagabbro mineral assemblage means that few equilibria are available for constraining its peak-metamorphic P-T conditions. Three wellcalibrated equilibria may be written amongst end-member components of the eclogitic assemblage Grt + Omp + Phe:

$$
\begin{aligned}
& \mathrm{Mg}_{3} \mathrm{Al}_{2} \mathrm{Si}_{3} \mathrm{O}_{12}+3 \mathrm{CaFeSi}_{2} \mathrm{O}_{6}=\mathrm{Fe}_{3} \mathrm{Al}_{2} \mathrm{Si}_{3} \mathrm{O}_{12}+3 \mathrm{CaMgSi}_{2} \mathrm{O}_{6} \\
& \text { garnet omphacite garnet omphacite } \\
& 2 \mathrm{Ca}_{3} \mathrm{Al}_{2} \mathrm{Si}_{3} \mathrm{O}_{12}+\mathrm{Mg}_{3} \mathrm{Al}_{2} \mathrm{Si}_{3} \mathrm{O}_{12}+3 \mathrm{KMgAlSi}_{4} \mathrm{O}_{10}(\mathrm{OH})_{2}=6 \mathrm{CaMgSi}_{2} \mathrm{O}_{6}+3 \mathrm{KAl}_{3} \mathrm{Si}_{3} \mathrm{O}_{10}(\mathrm{OH})_{2} \\
& \text { garnet garnet phengite omphacite phengite } \\
& \mathrm{Mg}_{3} \mathrm{Al}_{2} \mathrm{Si}_{3} \mathrm{O}_{12}+3 \mathrm{KFeAlSi}_{4} \mathrm{O}_{10}(\mathrm{OH})_{2}=\mathrm{Fe}_{3} \mathrm{Al}_{2} \mathrm{Si}_{3} \mathrm{O}_{12}+3 \mathrm{KMgAlSi}_{4} \mathrm{O}_{10}(\mathrm{OH})_{2} \\
& \text { garnet phengite garnet phengite. }
\end{aligned}
$$

Equilibrium A is temperature-sensitive and has been calibrated as a geothermometer by many workers, including Råheim and Green (1974), Ellis and Green (1979), Krogh (1988), Pattison and Newton (1989), Ai (1994) and Krogh-Ravna (2000). Equilibrium C can also be used as a thermometer and has been calibrated for metabasic compositions by Krogh and Råheim (1978). Equilibrium B is pressure-sensitive and has been calibrated as a geobarometer by Krogh-Ravna and Terry (2004).

The application of equilibria $\mathrm{A}, \mathrm{B}$ and $\mathrm{C}$ relies on the identification of equilibrated garnet, omphacite and phengite compositions. The variability of garnet and omphacite chemistry indicates that the metagabbro did not achieve equilibrium on a thin-section scale. Garnet cores and omphacites from the interiors of omphacite aggregates clearly failed to equilibrate at the peak of metamorphism. Because Fe-Mg partitioning between garnet and 
clinopyroxene (controlled by equilibrium A) results in $(\mathrm{Mg} / \mathrm{Fe})_{\mathrm{Cpx}}>(\mathrm{Mg} / \mathrm{Fe})_{\mathrm{Grt}}$ and decreases with increasing temperature, zoning profiles in eclogitic garnets that show smoothly increasing $(\mathrm{Mg} / \mathrm{Fe})_{\text {Grt }}$, such as observed in our data, may be assumed to record prograde garnet growth. Mn is also strongly partitioned into garnet. Thus, the lack of Fe,Mn-enriched garnet outer rims argues that garnet and omphacite underwent little or no retrogressive Fe-Mg exchange, and thus that the garnet outer Mg-rich rims represent the thermal peak of metamorphism. For present purposes, therefore, the compositions chosen for thermobarometry were the garnet rim with the highest $\mathrm{Mg} /(\mathrm{Fe}+\mathrm{Mg})$ value $(0.107)$, the adjacent omphacite, and the mean phengite.

Application of the equation of Krogh-Ravna and Terry (2004) for equilibrium B requires input of activity values for the component end-members. Activity-composition relations of minerals used with these calculations were: omphacite: ordered $P 2 / n$ pyroxene model of Holland (1990); white mica: ideal ionic mixing; garnet: regular solution model with $\mathrm{W}_{\mathrm{py}-\mathrm{alm}}=$ $2.5 \mathrm{kJmol}^{-1}$ and $\mathrm{W}_{\mathrm{py}-\mathrm{gr}}=33 \mathrm{kJmol}^{-1}$, as used in the program AX of Holland \& Powell (ftp://www.esc.cam.ac.uk/pub/minp/AX/), but multiplied by $\left(\mathrm{X}_{\mathrm{Si}}{ }^{\mathrm{IV}}\right)^{3}$ to take account of the minor $\mathrm{Si}=4 \mathrm{H}$ substitution on the tetrahedral sites.

The independent calibrations of Krogh-Ravna (2000) and Krogh-Ravna and Terry (2004) for equilibria A and B, respectively, yield an intersection at $1.99 \pm 0.32 \mathrm{GPa}$ and 525 $\pm 80{ }^{\circ} \mathrm{C}$ (Fig. 8). The calibration of Krogh and Råheim (1978) for equilibrium C suggests a slightly higher temperature and, if given equal weight to A and B, yields a 'best-fit' intersection close to $1.9 \mathrm{GPa}$ and $530{ }^{\circ} \mathrm{C}$ (Fig. 8).

Apart from the errors inherent in the calibrations, the main potential sources of error are (i) uncertainties in the $\mathrm{Fe}^{3+}$ contents of the minerals, and (ii) the suceptibility of phengite to retrograde diffusional Fe-Mg exchange. With regard to the first point, the temperatures returned by $\mathrm{Fe}, \mathrm{Mg}$-exchange thermometers are particularly sensitive to errors in the $\mathrm{Fe}^{3+}$ 
contents of clinopyroxene and phengite because these phases have low Fe/Mg ratios (as discussed for Grt-Cpx thermometry by Krogh Ravna 2000). In principle, $\mathrm{Fe}^{3+}$ contents could be obtained on omphacite separates by Mössbauer spectroscopy, but given the spatial variation in omphacite chemistry, this method could not produce trustworthy $\mathrm{Fe}^{3+}$ contents for the omphacites in equilibrium with garnet rims. Allowing some of the Fe in phengite to be $\mathrm{Fe}^{3+}$ has no effect on the temperature returned by the thermometer of Krogh and Råheim (1978) because this calibration rests on the assumption that all $\mathrm{Fe}$ in phengite is $\mathrm{Fe}^{2+}$. Fortunately, the fact that diopside and celadonite activities are relatively insensitive to the $\mathrm{Fe}^{3+}$ contents of their host minerals means that the pressures generated by equilibrium $\mathrm{B}$ are robust.

With regard to the issue of retrograde Fe-Mg exchange between mica and other phases, Spear (1993) has shown that the thermometric error will be greatest where the mica mode is small compared to that of other Fe, Mg-silicates, as in this case. Even though no retrograde Fe,Mg-exchange is detectable in garnet rims, the possibility remains that the compositions of the rare phengites were modified during cooling, which casts doubt on the robustness of garnet-phengite Fe-Mg exchange thermometry. In view of this, we prefer to take the intersection between equilibria $\mathrm{A}$ and $\mathrm{B}$ alone $\left(1.99 \mathrm{GPa}, 525^{\circ} \mathrm{C}\right.$; Fig. 8) as the best estimate of peak-metamorphic conditions.

The geobarometric results clearly indicate that the Lanzada metagabbro underwent metamorphism at modest temperature and great depth $(c a .70 \mathrm{~km})$. The implied 'average' geothermal gradient (obtained by dividing peak-metamorphic temperature by peakmetamorphic depth) is $c a .7 \pm 2{ }^{\circ} \mathrm{C} / \mathrm{km}$.

\section{Discussion and conclusions}


The $P-T$ conditions recorded by the Lanzada metagabbro are comparable to those recorded by high-pressure rocks in other ophiolitic units of the Alps, and they map onto the $P$ $T$ array defined by those data (Fig. 8). As with those other ophiolitic units, the low 'average' geothermal gradient obtained for the Lanzada metagabbro is entirely consistent with metamorphism in a subduction zone.

This is the first record of high-pressure metamorphism in the Lanzada window. The implication of this finding is that at least some parts of the cover sequence of the LSZ underwent subduction during Alpine ocean closure. Whether or not the whole of the LSZ cover was subducted to depths of $\geq 70 \mathrm{~km}$ is debateable. If it did, the other rocks within the window must have had eclogite-facies mineral assemblages totally overprinted by retrogressive assemblages. Given the small degree of retrogression in the metagabbro (which is consistent with the low grade of Lepontine regional metamorphism in the Penninic units east of the Bergell intrusion - Frey and Ferreiro-Mählmann 1999), this seems unlikely. An alternative scenario is one in which the LSZ comprises a tectonic mélange within which small fault-bouded lenses of subducted rock have become tectonically interleaved with lower-grade rocks during exhumation, as documented in some other subduction complexes (e.g. the Sistan Suture Zone, Iran - Rad et al. 2005). Establishing which of these two scenarios is correct will require further field and petrographic work.

Given the existence of blueschist-facies mineral assemblages in the Suretta nappe and Avers Bündnerschiefer, and the absence of high- $P$ assemblages in the Malenco unit, Platta, Margna and Sella nappes, our findings support Montrasio's (1984) correlation of the ophiolitic part of the LSZ with the Avers Bündnerschiefer and the orthogneisses with the Suretta nappe. If true, this would mean that the Avers unit preserves a southwards increase in peak pressure of $c a .0 .7 \mathrm{GPa}$ over a map distance of $c a .30 \mathrm{~km}$, providing further evidence in support of a southerly-dipping subduction zone. The only other unit for which a peak- $P$ 
gradient is documented for high- $P$ metamorphism is the Adula nappe (Heinrich 1986), in which peak pressure increases to the south by $c a .1 .0 \mathrm{GPa}$ over a map distance of $c a .40 \mathrm{~km}$ (Dale and Holland 2003). The correspondence between these two gradients is remarkable, especially when one recalls (a) that the LSZ and Adula nappe were subducted at different times and locations, and (b) that the present-day map-lengths of these units probably bear only an approximate relation to their true down-dip lengths within their respective subduction zones, as both units have undergone several phases of post-high- $P$ plastic deformation (Ring 1992; Zulbati 2008).

If the correlation of the ophiolitic component of the LSZ with the Avers Bündnerschiefer is correct, the Lanzada metagabbro is the most south-easterly-derived rock discovered so far in the eastern Central Alps that provides direct evidence of subduction of the Piemont-Ligurian oceanic crust. The peak pressure recorded by the Lanzada metagabbro is much higher than that recorded by the overlying Malenco unit and Margna nappe (Benning and Sidler 1992; Bissig and Hermann 1999; Müntener et al, 2000), indicating that the base of the Malenco unit represents an important metamorphic and tectonic discontinuity. That the retrograde P-T path of the Lanzada metagabbro was also different from that of the Malenco unit is qualitatively indicated by marked differences in the retrograde amphibole compositions (Fig. 5).

Bachmann et al. (2009) assumed that the deformation that they dated within the structurally higher (and therefore more south-easterly-derived) Platta nappe and lowermost Austroalpine basement reflected subduction, but as no high- $P$ metamorphic relics have been found in those units, the validity of the assumption is questionable. Equally possible, in our view, is that the dated deformation reflects a phase of crustal (re-)thickening by nappe stacking at the northern margin of Apulia prior to the onset of 'deep' subduction north-west of the original position of the Malenco unit. If, as argued by Froitzheim and Manatschal (1996) 
and Froitzheim et al. (1996), the protoliths of the Platta nappe became part of the PiemontLigurian ocean floor by denudation of the mantle along extensional normal faults rather than by spreading at an ocean ridge, then the deformation dated by Bachmann et al. (2009) within the Platta and lowermost Austroalpine nappes might merely reflect compressive (rethickening of the crust and restoration of the original superposition of Apulian continental crust upon Platta mantle. Such motion would still record an early phase of orogenic compression but would not require subduction.

Our geochemical data do not allow us to determine the original tectonic setting of the Lanzada metagabbro protolith. There is clear evidence that some Alpine (meta-)gabbros are of Permian age and of sub-continental origin (e.g. the Braccia gabbro of the Malenco unit Müntener and Hermann 1996; Hermann et al. 1997; Trommsdorff et al. 2005 -, the Fedoz gabbro of the Margna nappe - Ulrich and Borsien 1996 - and the Mont Collon gabbro of the Dent Blanche klippe - Monjoie et al. 2005) while others are of Jurassic age and of oceanic origin (e.g. the Mellichen and Allalin gabbros of the Zermatt-Saas zone - Rubatto et al. 1998). If the Lanzada metagabbro formed originally at an ocean ridge, its inferred Ca-metasomatism could have been due to epidotisation caused by ridge-related hydrothermal fluid circulation (e.g. Bickle and Teagle 1992). If, on the other hand, the Lanzada metagabbro was originally sub-continental, its inferred Ca-metasomatism is unlikely to have occurred while it was situated close to the crust-mantle boundary as there is little scope in that environment for the circulation of the necessary hydrous fluids. However, it is noteworthy that the LSZ contains ophicarbonates; similar rocks in the Malenco unit have been interpreted by Hermann and Müntener (1996) as having formed when sub-continental mantle peridotite was exposed at the ocean floor by rifting-related extensional normal faulting. Serpentinisation of the peridotites during this process could have resulted in partial rodingitisation of associated gabbro bodies. 
The age of the high- $P$ metamorphism of the Lanzada metagabbro is unknown. If the correlation of the LSZ with the Avers Bündnerschiefer is correct, an age within the range 50 $40 \mathrm{Ma}$ would be expected. Dating the eclogitic assemblage may be achievable through U-Pb dating of titanite or Sm-Nd dating of garnet-omphacite pairs, though the latter would be complicated by the documented thin-section-scale disequilibrium.

\section{Conclusions}

1. Epidote-rich eclogitic metagabbro forms a small body within the Lanzada Window, where it is associated with serpentinites and supracrustal rocks of the Lanzada - Santa Anna Zone (LSZ). This is the first record of high-pressure metamorphism in the Lanzada Window and in the Malenco region.

2. The peak-metamorphic mineral assemblage (garnet + omphacite + epidote + phengite + titanite + apatite + pyrite) crystallised at ca. $2.0 \mathrm{GPa}$ and $525^{\circ} \mathrm{C}$ and underwent only limited retrogressive alteration to an albite-epidote-amphibolite-facies assemblage. The deduced P-T conditions imply that at least parts of the LSZ were subducted to depths of $c a .70 \mathrm{~km}$.

3. The presence of eclogite within the LSZ strengthens the correlation of this unit with the blueschist-bearing Avers Bündnerschiefer, and confirms the former existence of a southerly-dipping subduction zone beneath the Malenco unit. If the correlation is true, the Lanzada metagabbro is the most south-easterly-derived rock discovered so far in the eastern Central Alps that provides direct evidence of subduction of Piemont-Ligurian oceanic crust. 4. The Lanzada metagabbro shows trace-element geochemical affinities with tholeiitic basalts. The bulk composition is Ca-rich (wollastonite-normative), suggesting that the rock underwent Ca-metasomatism prior to high- $P$ metamorphism. The metasomatism presumably occurred either by partial epidotisation during ocean-ridge-related hydrothermal circulation or 
by partial rodingitisation during extensional denudation and serpentinisation of mantle during slow spreading of the Piemont-Ligurian ocean in the Jurassic.

\section{Acknowledgements}

This study was supported by NERC grant NE/G018014/1. John Charnock and Paul

Lythgoe are thanked for help with the analytical work. Alison Pawley is thanked for assistance in the field. Helpful comments from Othmar Müntener are gratefully acknowledged.

\section{References}

Angiboust, S., Agard, P., Jolivet, L. \& Beyssac, O. (2009) The Zermatt-Saas ophiolite: the largest (60-km wide) and deepest (c. 70-80 km) continuous slice of oceanic lithosphere detached from a subduction zone? Terra Nova, 21, 171-180.

Ai, Y. (1994). A revision of the garnet-clinopyroxene $\mathrm{Fe}^{2+}-\mathrm{Mg}$ exchange geothermometer. Contributions to Mineralogy and Petrology, 115, 467-473.

Austrheim, H. \& Prestvik, T. (2008). Rodingitization and hydration of the oceanic lithosphere as developed in the Leka ophiolite, north-central Norway. Lithos, 104, 177-198.

Bachmann, R., Glodny, J., Oncken, O. \& Seifert, W. (2009). Abandonment of the South Penninic - Austroalpine palaeosubduction zone, Central Alps, and shift from subduction erosion to accretion: constraints from $\mathrm{Rb} / \mathrm{Sr}$ geochronology. Journal of the Geological Society, 166, 217-231.

Banerjee, N.R., Gillis, K.M. \& Muehlenbachs, K. (2000). Discovery of epidosites in a modern oceanic setting, the Tonga forearc. Geology, 28, 151-154. 
Bearth, P. \& Stern, W. (1971). Zum Chemismus der Eklogite und Glaukophanite von Zermatt. Schweizerische mineralogische und petrographische Mitteilungen, 51, 349359.

Becker, H. (1993). Garnet peridotite and eclogite Sm-Nd mineral ages from the Lepontine dome (Swiss Alps): New evidence for Eocene high-pressure metamorphism in the central Alps. Geology, 21, 599-602.

Benning, L.G. \& Sidler, D.M. (1992). Petrography at the contact of the Margna and Sella nappes and the Malenco serpentinite in the Pass d'Ur - Pizzo Scalino area (Val Malenco, Italy). Schweizerische mineralogische und petrographische Mitteilungen, $72,213-224$

Berger, A., Schmid, S.M., Engi, M., Bousquet, R. \& Wiederkehr, M. (2011). Mechanisms of mass and heat transport during Barrovian metamorphism: A discussion based on field evidence from the Central Alps (Switzerland / northern Italy). Tectonics, 30, TC1007, doi: 10.1029/2009TC002622.

Bickle, M.J. \& Teagle, D.A.H. (1992). Strontium alteration in the Troodos ophiolite implications for fluid fluxes and geochemical transport in midocean ridge hydrothermal systems. Earth and planetary Science Letters, 113, 219-237.

Bissig, T. \& Hermann, J. (1999). From pre-Alpine extension to Alpine convergence: the example of the southwestern margin of the Margna nappe (Val Malenco, N. Italy). Schweizerische mineralogische und petrographische Mitteilungen, 79, 363-380.

Bousquet, R., Goffé, B., Vidal, O., Oberhänsli, R. \& Patriat, M. (2002). The tectonometamorphic history of the Valaisan domain from the Western to the central Alps: New constraints on the evolution of the Alps. Geological Society of America Bulletin, $114,207-225$ 
Bousquet, R., Oberhänsli, R., Goffé, B., Jolivet, L. \& Vidal, O. (1998). High-pressure, lowtemperature metamorphism and deformation in the Bündnerschiefer of the Engadine window: implications for the regional evolution of the eastern Central Alps. Journal of metamorphic Geology, 16, 657-674.

Bowtell, S.A., Cliff, R.A. \& Barnicoat, A.C. (2007). Sm-Nd isotopic evidence on the age of eclogitization in the Zermatt-Saas ophiolite. Journal of metamorphic Geology, 12, 187-196.

Brouwer, F.M., Burri, T., Engi, M. \& Berger, A. (2005). Eclogite relics in the Central Alps: PT-evolution, Lu-Hf ages and implications for formation of tectonic mélange zones. Schweizerische mineralogische und petrographische Mitteilungen, 85, 147-174.

Brouwer, F.M., Vissers, R.L.M. \& Lamb, W.M. (2002). Metamorphic history of eclogitic metagabbro blocks from a tectonic melange in the Voltri Massif, Ligurian Alps, Italy. Ofioliti, 27, 1-16.

Bucher, K. \& Grapes, R. (2009). The eclogite-facies Allalin Gabbro of the Zermatt-Saas Ophiolite, Western Alps: a record of subduction-zone hydration. Journal of Petrology, $50,1405-1442$.

Carswell, D.A. (Ed.) (1990). Eclogite facies rocks. (396pp.). Glasgow: Blackie.

Coleman, R.G. (1967). Low-temperature reaction zones and alpine ultramafic rocks of California, Oregon and Washington. U.S. Geological Survey Bulletin, 1247, 1-49.

Colombi, A. \& Pfeifer, H.R. (1986). Ferrogabboic and basaltic meta-eclogites from the Antrona mafic-ultramafic complex and the Centovalli-Locarno region (Italy and southern Switzerland) - first results. Schweizerische mineralogische und petrographische Mitteilungen, 66, 99-110. 
Dale, J. \& Holland, T.J.B. (2003). Geothermobarometry, P-T paths and metamorphic field gradients of high-pressure rocks from the Adula Nappe, Central Alps. Journal of metamorphic Geology, 23, 771-791.

Dickin, A.P. \& Jones, N.W. (1983). Relative elemental mobility during hydrothermal alteration of a basic sill, Isle of Skye, Scotland. Contributions to Mineralogy and Petrology, 82, 147-153.

Dachs, E. \& Proyer, A. (2001). Relics of high-pressure metamorphism from the Grossglockner region, Hohe Tauern, Austria: Paragenetic evolution and P-T paths of retrogressed eclogites. European Journal of Mineralogy, 13, 67-86.

Droop, G.T.R. (1987). A general equation for estimating $\mathrm{Fe}^{3+}$ concentrations in ferromagnesian silicates and oxides from microprobe analyses, using stoichiometric criteria. Mineralogical Magazine, 51, 431-435.

Ellis, D.J. \& Green, D.H. (1979). An experimental study of the effect of Ca upon garnetclinopyroxene Fe-Mg exchange equilibria. Contributions to Mineralogy and Petrology, 71, 13-22.

Ernst, W.G. (1973). Blueschist metamorphism and P-T regimes in active subduction zones. Tectonophysics, 17, 255-272.

Ernst, W.G. (1977). Mineralogic study of eclogitic rocks from Alpe Arami, Lepontine Alps, southern Switzerland. Journal of Petrology, 18, 371-398.

Ernst, W.G. \& Dal Piaz, G.V. (1978). Mineral parageneses of eclogitic rocks and related mafic schists of the Piemonte ophiolite nappe, Breuil- St. Jacques area, Italian Western alps. American Mineralogist, 63, 621-640.

Essene, E.J. \& Fyfe, W.S. (1967). Omphacite in Californian metamorphic rocks. Contributions to Mineralogy and Petrology, 15, 1-23. 
Evans, B.W. \& Brown, E. (Eds.) (1986). Blueschists and eclogites. Geological Society of America Memoir, 164, 423pp. Boulder: The Geological Society of America.

Evans, B.W. \& Trommsdorff, V. (1978). Petrogenesis of garnet lherzolite, Cima di Gagnone, Lepontine Alps. Earth and planetary Science Letters, 40, 333-348.

Evans, B.W., Trommsdorff, V. \& Goles, G.G. (1981). Geochemistry of high-grade eclogites and metarodingites from the Central Alps. Contributions to Mineralogy and Petrology, 76, 301-311.

Floyd, P.A. \& Winchester, J.A. (1975). Magma type and tectonic discrimination using immobile elements. Earth and planetary Science Letters, 27, 211-218.

Frey, M., Desmons, J. \& Neubauer, F. (1999). The new metamorphic map of the Alps: Introduction. Schweizerische mineralogische und petrographische Mitteilungen, 79, 14 .

Frey, M. \& Ferreiro-Mählmann, R. (1999). Alpine metamorphism of the central Alps. Schweizerische mineralogische und petrographische Mitteilungen, 79, 135-154.

Frisch, W. (1979). Tectonic progradation and plate tectonic evolution of the Alps. Tectonophysics, 60, 121-139.

Froitzheim, N. \& Manatschal, G. (1996). Kinematics of Jurassic rifting, mantle exhumation, and passive-margin formation in the Austroalpine and Penninic nappes (eastern Switzerland). Geological Society of America Bulletin, 108, 1120-1133.

Froitzheim, N., Schmid, S.M. \& Frey, M. (1996). Mesozoic paleogeography and the timing of eclogite-facies metamorphism in the Alps: a working hypothesis. Eclogae Geologicae Helvetiae, 89, 81-110.

Gebauer, D. (1996). A P-T-t path for an (ultra?-)high-pressure ultramafic-mafic rock association and its felsic country rocks based on SHRIMP-dating of magmatic and metamorphic zircon domains. Example: Alpe Arami (Central Swiss Alps). In A. Basu 
\& S. Hart, (Eds.), Earth Processes: Reading the Isotopic Code. Geophysical Monograph, 95 (pp. 307-330). Washington: American Geophysical Union.

Gebauer, D. (1999). Alpine geochronology of the Central and Western Alps: new constraints for a complex geodynamic evolution. Schweizerische mineralogische und petrographische Mitteilungen, 79, 191-208.

Gieré, R. (1985). Metasedimente der Suretta-Decke am Ost- und Südostrand der Bergeller Intrusion: Lithostratigraphische Korrelation und Metamorphose. Schweizerische mineralogische und petrographische Mitteilungen, 65, 57-78.

Goffé, B. \& Oberhänsli, R. (1992). Ferro- and magnesio-carpholite in the Bündnerschiefer of the eastern Central Alps (Grisons and Engadine Window). European Journal of Mineralogy, 4, 835-838.

Handy, M.R., Schmid, S.M., Bousquet, R., Kissling, E. \& Bernoulli, D. (2010). Reconciling plate-tectonic reconstructions of Alpine Tethys with the geological-geophysical recors of spreading and subduction in the Alps. Earth Science Reviews, 102, 121-158.

Hansmann, W. (1996). Age determinations on the Tertiary Masino-Bregaglia (Bergell) intrusives (Italy, Switzerland): a review. Schweizerische mineralogische und petrographische Mitteilungen, 76, 421-451.

Heinrich, C.A. (1986). Eclogite-facies regional metamorphism of hydrous mafic rocks in the Central Alpine Adula nappe. Journal of Petrology, 27, 123-154.

Hermann, J. \& Müntener, O. (1996). extension-related structures in the Malenco-Margna system: implications for palaeogeography and consequences for rifting and Alpine tectonics. Schweizerische mineralogische und petrographische Mitteilungen, 76, 501519. 
Hermann, J., Müntener, O., Trommsdorff, V., Hansmann, W. \& Piccardo, G.B. (1997). Fossil crust-to-mantle transition, Val Malenco (Italian Alps). Journal of geophysical Research, 102, 20,123-20,132.

Honnorez, J. \& Kirst, P. (1975). Petrology of rodingites from the Equatorial Mid-Atlantic fracture zones and their tectonic significance. Contributions to Mineralogy and Petrology, 49,233-257.

Holland, T.J.B. (1990). Activities of components in omphacitic solid solutions: an application of Landau theory to mixtures. Contributions to Mineralogy and Petrology, 105, 446-453.

Hoschek, G. (2007). Metamorphic peak conditions of eclogites in the Tauern Window, Eastern Alps, Austria: Thermobarometry of the assemblage garnet plus omphacite plus phengite plus kyanite plus quartz. Lithos, 93, 1-16.

Jowitt, S.M., Jenkin, G.R.T., Coogan, L.A. \& Naden, J. (2012). Quantifying the release of base metals from source rocks for volcanogenic massive sulfide deposits: effects of protolith composition and alteration mineralogy. Journal of geochemical Exploration, $118,47-59$.

Kretz, R. (1983). Symbols for rock-forming minerals. American Mineralogist, 68, 277-279.

Krogh, E.J. (1988). The garnet-clinopyroxene Fe-Mg geothermometer - a reinterpretation of existing experimental data. Contributions to Mineralogy and Petrology, 99, 44-48.

Krogh, E.J. \& Råheim, A. (1978). Temperature and pressure dependence of Fe-Mg partitioning between garnet and phengite, with particular reference to eclogites. Contributions to Mineralogy and Petrology, 66, 75-80.

Krogh-Ravna, E.J. (2000). The garnet-clinopyroxene $\mathrm{Fe}^{2+}-\mathrm{Mg}$ geothermometer: an updated calibration. Journal of metamorphic Geology, 18, 211-219. 
Krogh-Ravna, E.J. \& Terry, M.P. (2004). Geothermobarometry of UHP and HP eclogites and schists - an evaluation of equilibria among garnet-clinopyroxene-kyanite-phengitecoesite/quartz. Journal of metamorphic Geology, 22, 579-592.

Laird, J. \& Albee, A.L. (1981). Pressure, temperature and time indicators in mafic schist: their application to reconstructing the polymetamorphic history of Vermont. American Journal of Science, 281, 127-175.

Leake, B.E. et al. (1997). Nomenclature of amphiboles: report of the Subcommittee on Amphiboles of the International Mineralogical Association on New Minerals and Mineral Names. Mineralogical Magazine, 61, 295-321.

Le Maitre, R.W. (1976). The chemical variability of some common igneous rocks. Journal of Petrology, 17, 589-637.

Li, X.P., Rahn, M. \& Bucher, K. (2008). Eclogite facies metarodingites - phase relations in the system $\mathrm{SiO}_{2}-\mathrm{Al}_{2} \mathrm{O}_{3}-\mathrm{Fe}_{2} \mathrm{O}_{3}-\mathrm{FeO}-\mathrm{MgO}-\mathrm{CaO}-\mathrm{CO}_{2}-\mathrm{H}_{2} \mathrm{O}$ : an example from the Zermatt-Saas ophiolite.

Martin, S., Rebay, G., Kienast, J.R. \& Mevel, C. (2008). An eclogitised oceanic palaeohydrothermal field from the St. Marcel Valley (Italian Western Alps). Ofioliti, 33, 4963.

Martin, S. \& Tartarotti, P. (1989). Polyphase HP metamorphism in the ophiolitic glaucophanites of the lower St Marcel Valley (Aosta, Italy). Ofioliti, 14, 135-156.

Messiga, B., Kienast, J.R., Rebay, G., Riccardi, M.P. \& Tribuzio, R. (1999). Cr-rich magnesiochloritoid eclogites from the Monviso ophiolites (Western Alps, Italy). Journal of metamorphic Geology, 17, 287-299.

Meyre, C., de Capitani, C. \& Partzsch, J.H. (1997). A ternary solid solution model for omphacite and its application to geothermobarometry of eclogites from the middle 
Adula nappe (Central Alps, Switzerland). Journal of metamorphic Geology, 15, 687700.

Mohn, G., Manatschal, G., Masini, E. \& Müntener, O. (2011). Rift-related inheritance in orogens: a case study from the Austroalpine nappes in Central Alps (SE Switzerland and N Italy). International Journal of Earth Sciences, 99, 937-961.

Mohn, G., Manatschal, G., Müntener, O., Beltrando, M. \& Masini, E. (2010). Unravelling the interaction between tectonic and sedimentary processes during lithospheric thinning in the Alpine Tethys margins. International Journal of Earth Sciences, 99 (supplement), S75-S101.

Monjoie, P., Bussy, F., Lapierre, H. \& Pfeifer, H.-R. (2005). Modeling of in-situ crystallization processes in the Permian mafic layered intrusion of Mont Collon (Dent Blanche nappe, western Alps). Lithos, 83, 317-346.

Montrasio, A. (1984). The "Lanzada-Scermendone Zone": an ophiolitic unit of continental affinity in the southern Rhaetic Alps (prov. Sondrio - Italy). Schweizerische mineralogische und petrographische Mitteilungen, 64, 111-129.

Montrasio, A., Trommsdorff, V., Hermann, H., Müntener, O. \& Spillmann, P. (2005). Carta Geologica della Valmalenco. Supplement to: Schweizerische mineralogische und petrographische Mitteilungen, 85, 1-13.

Müntener, O. \& Hermann, J. (1996). The Val Malenco lower crust - upper mantle complex and its field relations (Italian Alps). Schweizerische mineralogische und petrographische Mitteilungen, 76, 475-500.

Müntener, O., Hermann, J. \& Trommsdorff, V. (2000). Cooling history and exhumation of lower-crustal granulite and upper mantle (Malenco, Eastern Central Alps). Journal of Petrology, 41, 175-200. 
Nehlig, P., Juteau, T., Bendel, V. \& Cotten, J. (1994). The root zones of oceanic hydrothermal systems - constraints from the Samail ophiolite, Oman. Journal of geophysical Research - Solid Earth, 99, 4703-4713.

Nimis, P. \& Trommsdorff, V. (2001). Revised thermobarometry of Alpe Arami and other garnet peridotites from the central Alps. Journal of Petrology, 42, 103-115.

Nussbaum, C., Marquer, D. \& Biino, G.G. (1998). Two subduction events in a polycyclic basement: Alpine and pre-Alpine high-pressure metamorphism in the Suretta nappe, Swiss Eastern Alps. Journal of metamorphic Geology, 16, 591-605.

Oberhänsli, R. (1978). Chemische Untersuchungen an Glaukophan-führenden basischen Gesteinen aus den Bündnerschiefern Graubündens. Schweizerische mineralogische und petrographische Mitteilungen, 58, 139-156.

Oberli, F., Meier, M., Berger, A., Rosenberg, C. \& Gieré, R. (2004). U-Th-Pb and Th-230/U230 disequilibrium isotope systematics: precise accessory mineral chronology and melt evolution tracing in the Alpine Bergell intrusion. Geochimica et Cosmochimica Acta, 68, 2543-2560.

O’Hara, M.J. \& Mercy, E.L.P. (1966). Garnet-peridotite and eclogite from Bellinzona, Switzerland. Earth and planetary Science Letters, 1, 295-300.

Okamoto, K. \& Maruyama, S. (1999). The high-pressure synthesis of lawsonite in the MORB $+\mathrm{H}_{2} \mathrm{O}$ system. American Mineralogist, 84, 362-373.

Pattison, D.R.M. \& Newton, R.C. (1989). Reversed experimental calibration of the garnetclinopyroxene $\mathrm{Fe}-\mathrm{Mg}$ exchange geothermometer. Contributions to Mineralogy and Petrology, 101, 87-103.

Pelletier, L. \& Muntener, O. (2006). High-pressure metamorphism of the Lanzo peridotite and its oceanic cover, and some consequences for the Sesia-Lanzo zone (northwestern Italian Alps). Lithos, 90, 111-130. 
Pfeifer, H.R., Colombi, A., Ganguin, J., Hunziker, J.C., Oberhänsli, R. \& Santini, L. (1991). Relics of high-pressure metamorphism in different lithologies of the Central Alps, an updated inventory. Schweizerische mineralogische und petrographische Mitteilungen, $71,441-451$.

Pouchou, J.L. \& Pichoir, F. (1991). Quantitative analysis of homogeneous or stratified microvolumes applying the model "PAP". In K.F.J. Heinrich \& D.E. Newbury, (Eds.), Electron Probe Quantitation (pp. 31-76). New York: Plenum Press.

Rad, G.R.F., Droop, G.T.R., Amini, S. \& Moazzen, M. (2005). Eclogites and blueschists of the Sistan Suture Zone, eastern Iran: a comparison of P-T histories from a subduction mélange. Lithos, 84, 1-24.

Råheim, A. \& Green, D.H. (1974). Experimental determination of the temperature and pressure dependence of the $\mathrm{Fe}-\mathrm{Mg}$ partition coefficient for coexisting garnet and clinopyroxene. Contributions to Mineralogy and Petrology, 48, 179-203.

Reinecke, T. (1991). Very-high-pressure metamorphism and uplift of coesite-bearing metasediments from the Zermatt-Saas Zone, Western Alps. European Journal of Mineralogy, 3, 7-17.

Ring, U. (1992). The Alpine geodynamic evolution of Penninic nappes in the eastern Central Alps: geothermobarometric and kinematic data. Journal of metamorphic Geology, 10, $33-54$.

Rose, N.M. \& Bird, D.K. (1994). Hydrothermally altered dolerite dykes in East Greenland: implications for Ca-metasomatism of basaltic protoliths. Contributions to Mineralogy and Petrology, 116, 420-432.

Rubatto, D., Gebauer, D. \& Fanning, M. (1998). Jurassic formation and Eocene subduction of the Zermatt - Saas-Fee ophiolites: implications for the geodynamic evolution of the Central and Western Alps. Contributions to Mineralogy and Petrology, 132, 269-287. 
Rubatto, D., Hermann, J., Berger, A. \& Engi, M. (2009). Protracted fluid-induced melting during Barrovian metamorphism in the Central Alps. Contributions to Mineralogy and Petrology, 158, 703-722.

Schmid, S.M., Bernoulli, D., Fügenschuh, B., Matenco, L., Schefer, S., Schuster, R., Tischler, M. \& Ustaszewski, K. (2008). The Alpine-Carpathian-Dinaridic orogenic system: correlation and evolution of tectonic units. Swiss Journal of Geosciences, 101, 139183.

Schmid, S.M., Fügenschuh, B., Kissling, E. \& Schuster, R. (2004). Tectonic map and overall architecture of the Alpine orogen. Eclogae Geologicae Helvetiae, 97, 93-117.

Schmid, S.M., Pfiffner, O.A., Froitzheim, N., Schönborn, G. \& Kissling, E. (1996). Geophysical-geological transect and tectonic evolution of the Swiss-Italian Alps. Tectonics, 15, 1036-1064.

Spear, F.S. (1993). Metamorphic phase equilibria and pressure-temperature-time paths (799pp.). Washington DC: Mineralogical Society of America.

Spicher, A. (Ed.) (1980). Tektonische Karte der Schweiz, 1:500,000. $2^{\text {nd }}$ edition. Schweizerischen Geologischen Kommission.

Thompson, P.H. (1976). Isograd patterns and pressure-temperature distribution during regional metamorphism. Contributions to Mineralogy and Petrology, 57, 277-295.

Todd, C.S. \& Engi, M. (1997). Metamorphic field gradients in the central Alps. Journal of metamorphic Geology, 15, 513-530.

Tóth, T.M., Granjean, V. \& Engi, M. (2000). Polyphase evolution and reaction sequence of compositional domains in metabasalt: a model based on local chemical equilibrium and metamorphic differentiation. Geological Journal, 35, 163-183.

Trommsdorff, V. (1980). Alpine metamorphism and Alpine intrusions. In R. Trümpy, (Ed.), Geology of Switzerland, a guide-book (pp. 82-87). Basel: Wepf. 
Trommsdorff, V. (1990). Metamorphism and tectonics in the Central Alps: the Alpine evolution of the lithospheric mélange of Cima Lunga and Adula. Mem. Soc. Geol. It., $45,39-49$.

Trommsdorff, V., Montrasio, A. \& Hermann, J. (2005). The geological map of Valmalenco. Schweizerische mineralogische und petrographische Mitteilungen, 85, 1-13.

Trommsdorff, V., Piccardo, G.B. \& Montrasio, A. (1993). From magmatism through metamorphism to sea floor emplacement of subcontinental Adria lithosphere during pre-Alpine rifting (Malenco, Italy). Schweizerische mineralogische und petrographische Mitteilungen, 73, 191-203.

Trümpy, R. (1980). Geology of Switzerland: a guide-book. (104 pp.). Basel: Wepf. Ulrich, T. \& Borsien, G.-R. (1996). Fedozer Metagabbro und Forno Metabasalt (Val Malenco, Norditalien): Vergleichende petrographische und geochemische Untersuchungen. Schweizerische mineralogische und petrographische Mitteilungen, $76,521-535$.

Villa, I.M., Hermann, J., Müntener, O. \& Trommsdorff, V. (2000). ${ }^{39} \mathrm{Ar}-{ }^{40} \mathrm{Ar}$ dating of multiply zoned amphibole generations (Malenco, Italian Alps). Contributions to Mineralogy and Petrology, 140, 363-381.

von Blanckenburg, F. (1992). Combined high-precision chronometry and geochemical tracing using accessory minerals - applied to the central-Alpine Bergell intrusion (central Europe). Chemical Geology, 100, 19-40.

von Blanckenburg, F. \& Davies, J.H. (1995). Slab breakoff: A model for syncollisional magmatism and tectonics in the Alps. Tectonics, 14, 120-131.

Vuagnat, M. (1967). Quelques reflexions sur les ophispherites et les rodingites. Soc. Italiana Min. Pet. Rendus, 23, 471-482. 
Wang, J.P., Kusky, T.M., Polat, A., Wang, L., Peng, S.B., Jiang, X.F., Deng, H. \& Wang, S.J. (2012). Sea-floor metamorphism recorded in epidosites from the $c a$. 1.0Ga Miaowan Ophiolite, Huangling Anticline, China. Journal of Earth Science, 23, 696-704.

Wenner, D.B. (1979). Hydrogen, oxygen and carbon isotopic evidence for the origin of rodingites in serpentinized ultramafic rocks. Geochimica et Cosmochimica Acta, 43, 603-614.

Widmer, T., Ganguin, J. \& Thompson, A.B. (2000). Ocean-floor hydrothermal veins in eclogite-facies rocks of the Zermatt-Saas Zone, Switzerland. Schweizerische mineralogische und petrographische Mitteilungen, 80, 63-73.

Wiederkehr, M., Bousquet, R., Schmid, S. \& Berger, A. (2008). From subduction to collision: thermal overprint of HP/LT meta-sediments in the north-eastern Lepontine Dome (Swiss Alps) and consequences regarding the tectono-metamorphic evolution of the Alpine orogenic wedge. Swiss Journal of Geosciences, 101, Supplement 1, S127S155.

Wiederkehr, M., Sudo, M., Bousquet, R., Berger, A. \& Schmid, S. (2009). Alpine orogenic evolution from subduction to collision thermal overprint: The ${ }^{40} \mathrm{Ar} /{ }^{39} \mathrm{Ar}$ age constraints from the Valaisian Ocean, central Alps. Tectonics, 28, TC6009, doi:10.1029/2009TC002496.

Zanoni, D., Rebay, G., Spalla, M.I. \& Bernardoni, J. (2011). Eclogitised rodingites of the Zermatt-Saas Zone: unravelling their evolution through deformation-metamorphism relationships. Rendiconti online Soc. Geol. It., 15, 125-128.

Zulbati, F. (2008). Structural and metamorphic evolution of the phengite-bearing schists of the northern Adula Nappe Complex (Central Alps, Switzerland). Geological Journal, $43,82-103$. 


\section{Figure captions}

Fig. 1. Tectonic map of the eastern Central Alps (simplified from Montrasio et al., 2005, with boundaries extrapolated across unexposed areas). Star: eclogite locality. A-G: Adula Nappe including Gruf mass; Av: Avers Bundnerschiefer; B-D: Bellinzona-Dascio Zone; Ca: Campo and Languard nappes; Ch: Chiavenna Ophiolite; E-B: Err-Bernina nappe complex; EL: Engadine Line; Gr: Grosina Nappe; IL: Insubric Line; M-F: Malenco-Forno Unit; Ma: Margna Nappe; P1: Platta Nappe; Se: Sella Nappe; Su: Suretta Nappe; Ta: Tambo Nappe; To: Tonale Series.

Fig. 2. (a) Photomicrograph showing the irregular lobate rim region of a garnet porphyroblast (Grt) and associated omphacite (Cpx), epidote (Ep), titanite (Ttn) and retrograde albite (Ab) and hornblende ( $\mathrm{Hbl})$. (b) Photomicrograph showing retrograde hornblende ( $\mathrm{Hbl}$ ) cutting across a foliation defined by aligned omphacite (Cpx) (locally rich in dark fluid incusions) and epidote (Ep) and containing relict inclusions of those minerals.

Fig. 3. Compositional zoning profile across a garnet porphyroblast.

Fig. 4. Clinopyroxene compositions shown on the diagram of Essene and Fyfe (1967). 'Z-S Cpx’: mean of 11 omphacite analyses from the Zermatt-Saas zone (Ernst \& Dal Piaz 1978).

Fig. 5. Amphibole compositions shown on the $100 \mathrm{Na} /(\mathrm{Na}+\mathrm{Ca})$ vs. $100 \mathrm{Al} /(\mathrm{Al}+\mathrm{Si})$ plot of Laird and Albee (1981), in comparison with retrograde hornblendes of the Braccia Gabbro in the Malenco unit (Müntener et al. 2000), hornblendes of the Margna nappe (Benning \& Sidler 1992), and hornblendes and barroisites of the Zermatt-Saas zone (Ernst \& Dal Piaz 1978).

Fig. 6. Bulk composition of the Lanzada metagabbroic eclogite compared with compositions of variably metasomatised metabasalts from the Zermatt-Saas Zone, Western Alps, on 
the $\mathrm{CaO}-\mathrm{MgO}-\mathrm{Na}_{2} \mathrm{O}$ (wt.\%) plot of Widmer et al. (2000). Field of mid-ocean ridge basalts (MOR) and all Zermatt-Saas data from Widmer et al. (2000). Compositions of Cima Lunga basalt-metarodingite suite from Evans et al. (1981).

Fig. 7. Bulk composition of the Lanzada metagabbroic eclogite on the $\mathrm{TiO}_{2}$ versus $\mathrm{Y} / \mathrm{Nb}$ plot of Floyd and Winchester (1975).

Fig. 8. Garnet-clinopyroxene-phengite thermobarometry of the Lanzada metagabbroic eclogite. See text for explanation. Mineral component abbreviations from Kretz (1983). Circle: approximate 'best-fit' intersection generated by independently calibrated thermobarometers. Shaded area: error box for equilibria A and B. Facies boundaries from Okamoto and Maruyama (1999). $P-T$ conditions estimated for high- $P$ metamorphism in other Penninic ophiolitic units in the Alps: AL: Zermatt-Saas Zone Allalin Gabbro (Bucher and Grapes, 2009); AV: Avers Bundnerschiefer (Ring, 1992); LC: Lago di Cignana Unit (Reinecke, 1991); LZ: Lanzo peridotite (Pelletier and Muntener, 2006); MV: Monviso Complex (Messiga et al., 1999); SM: Zermatt-Saas Zone - St Marcel (Martin et al., 2008); TE: Tauern Eclogite Zone (Hoschek, 2007); TG: Tauern Glockner Nappe (Dachs and Proyer, 2001); ZS: Zermatt-Saas Zone (Angiboust et al., 2009).

\section{Table headings}

Table 1. Representative electron-microprobe analyses of peak-metamorphic and retrograde minerals. Garnet analyses 1,2 and 4 are from the same porphyroblast; epidote analyses 1 and 2 are from the same crystal; all other analyses are from different crystals. Abbreviations: 'cont.': contacting; 'dist.': distant from; 'Cpx agg.': in interior of Cpx aggregate; 'poik.': poikiloblast.

Table 2. Bulk chemical composition of the Lanzada metagabbroic eclogite. 


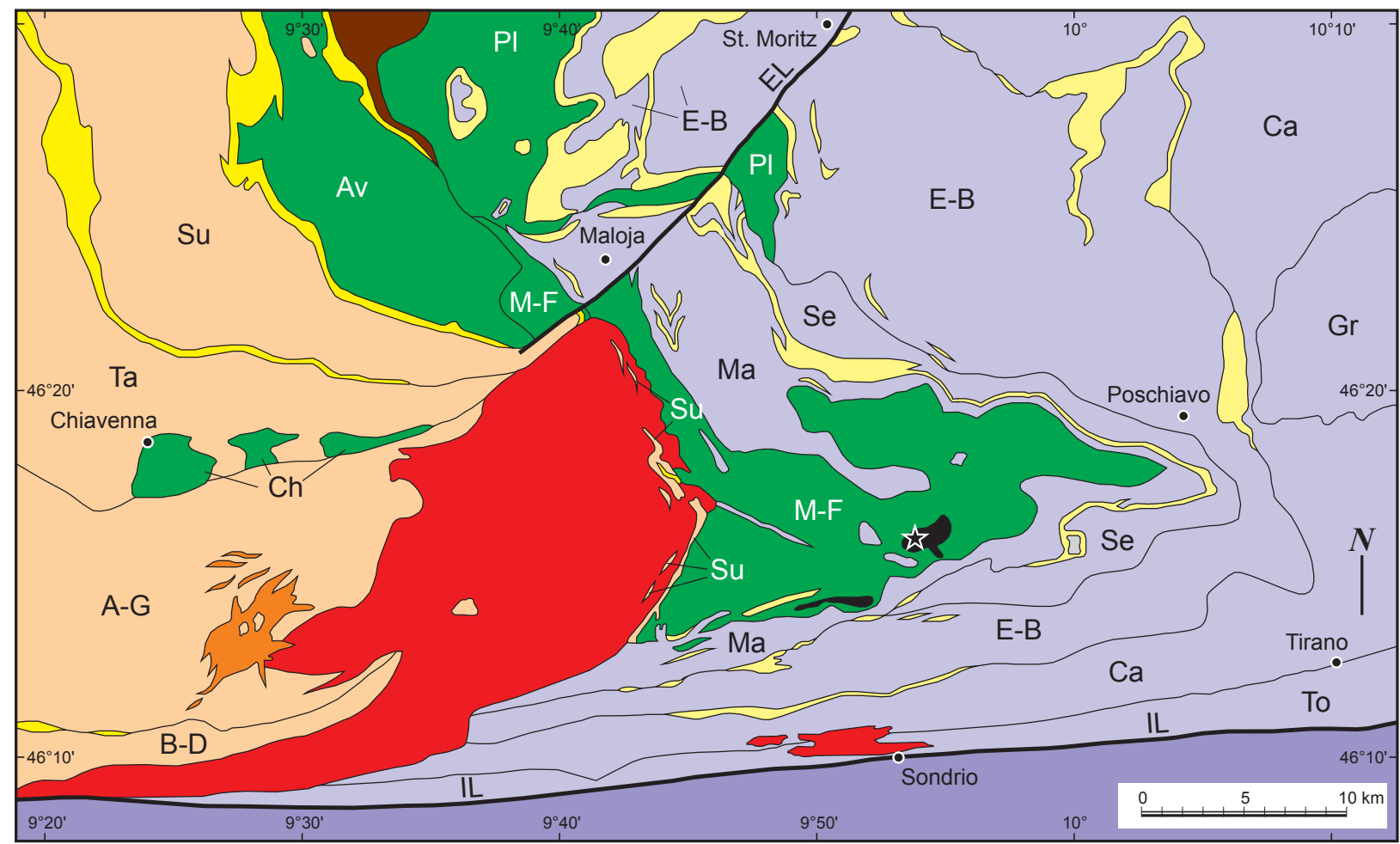

Tertiary leucogranite (Novate)
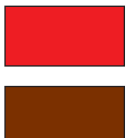

Tertiary tonalite \& granodiorite (Bergell, Triangia)

Tertiary flysch

Penninic Permo-Mesozoic metasedimentary cover

Austroalpine Permo-Mesozoic metasedimentary cover

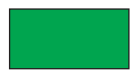

Ophiolitic units

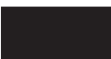

Lanzada - Santa Anna unit

Penninic basement nappes

Austroalpine basement nappes

Southern Alps 
Figure 2a

Click here to download high resolution image

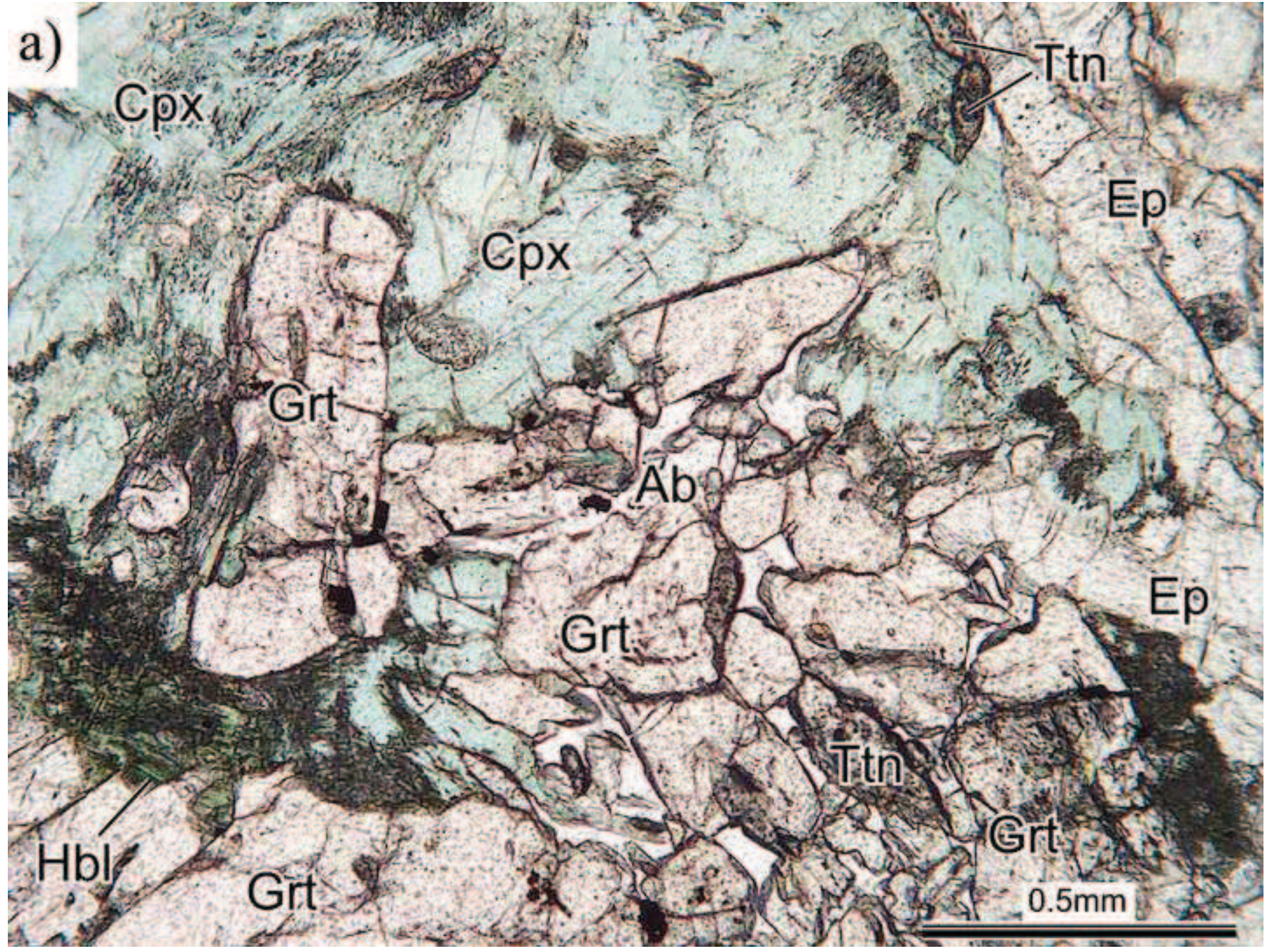


Figure $2 b$

Click here to download high resolution image

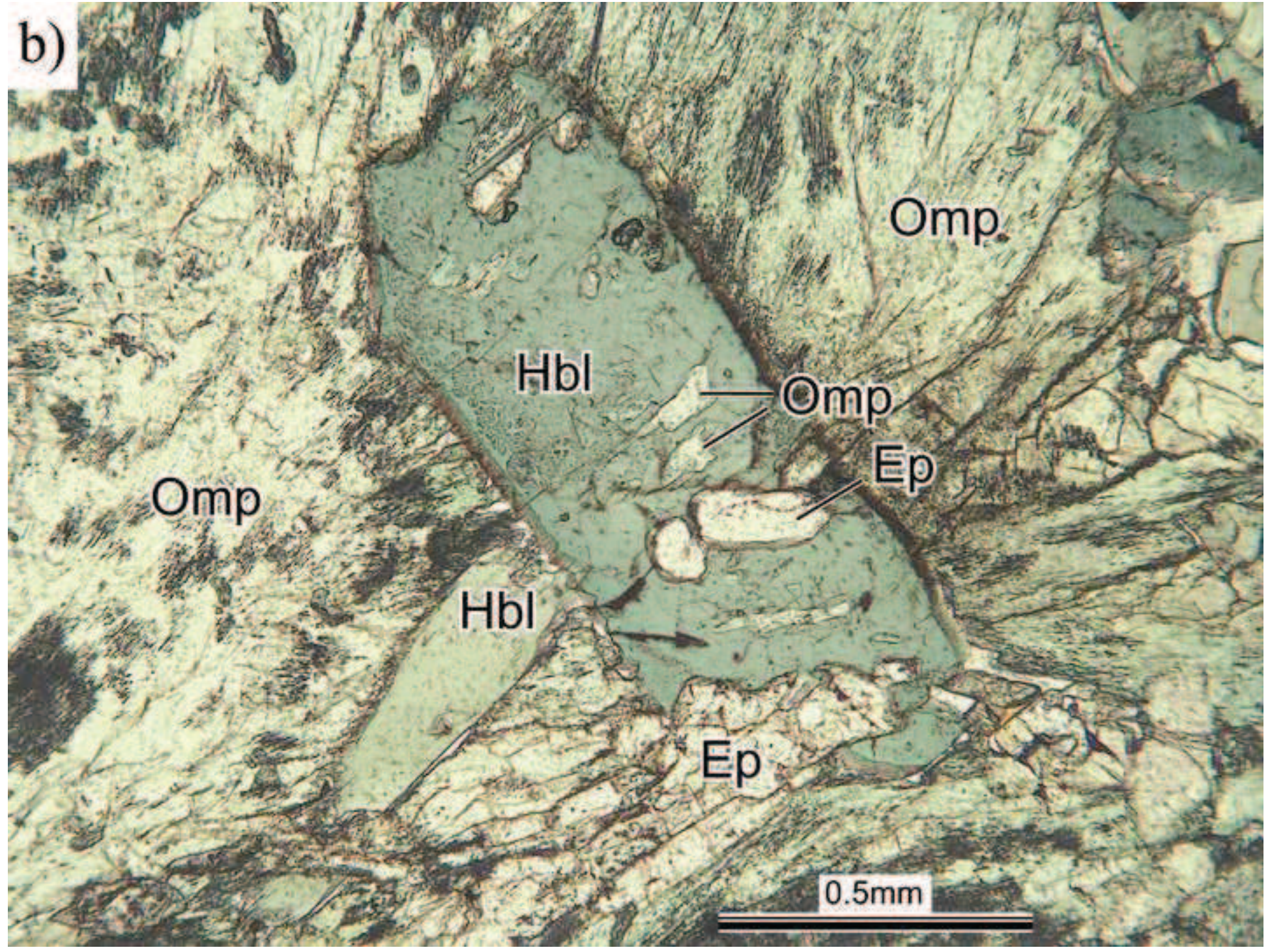


Figure 3

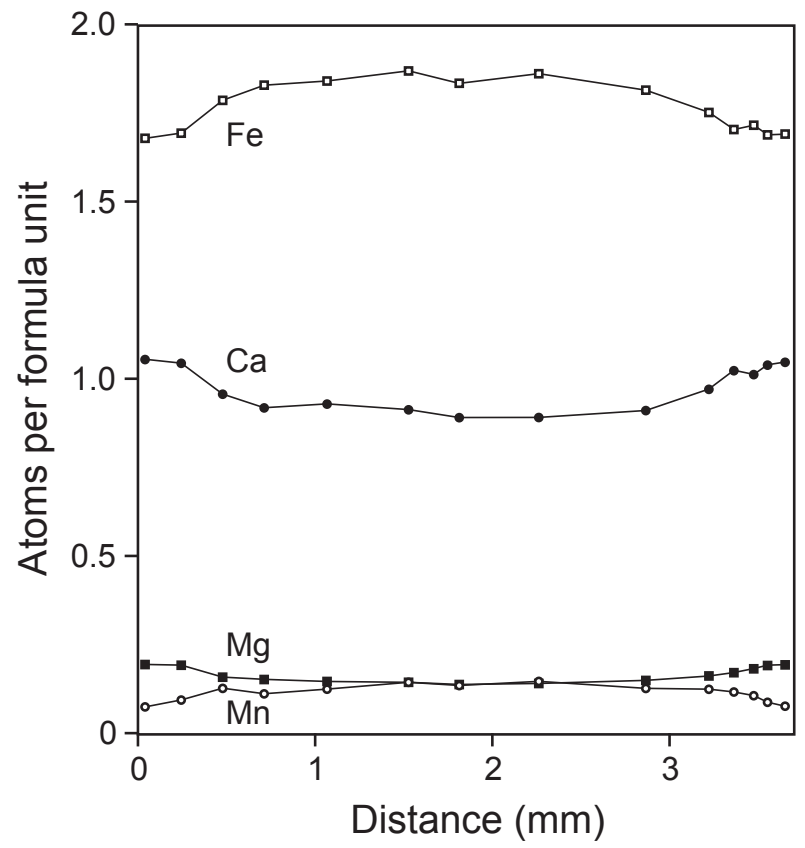


Figure 4

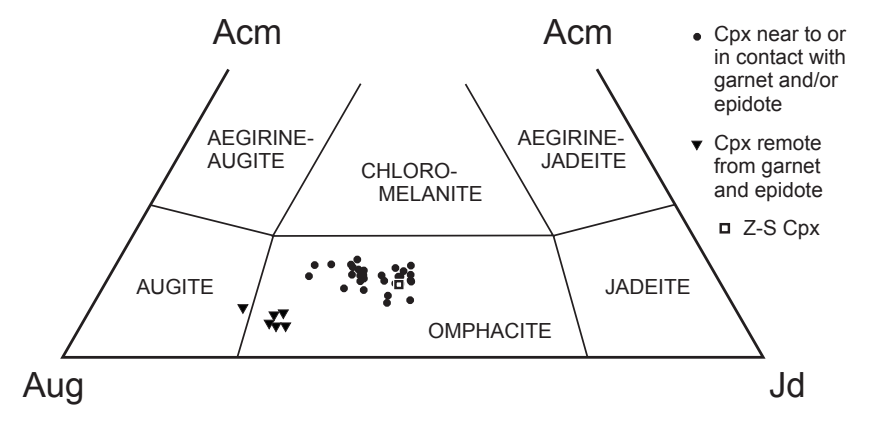

Aug Jd

Aug Jd . 
Figure 5

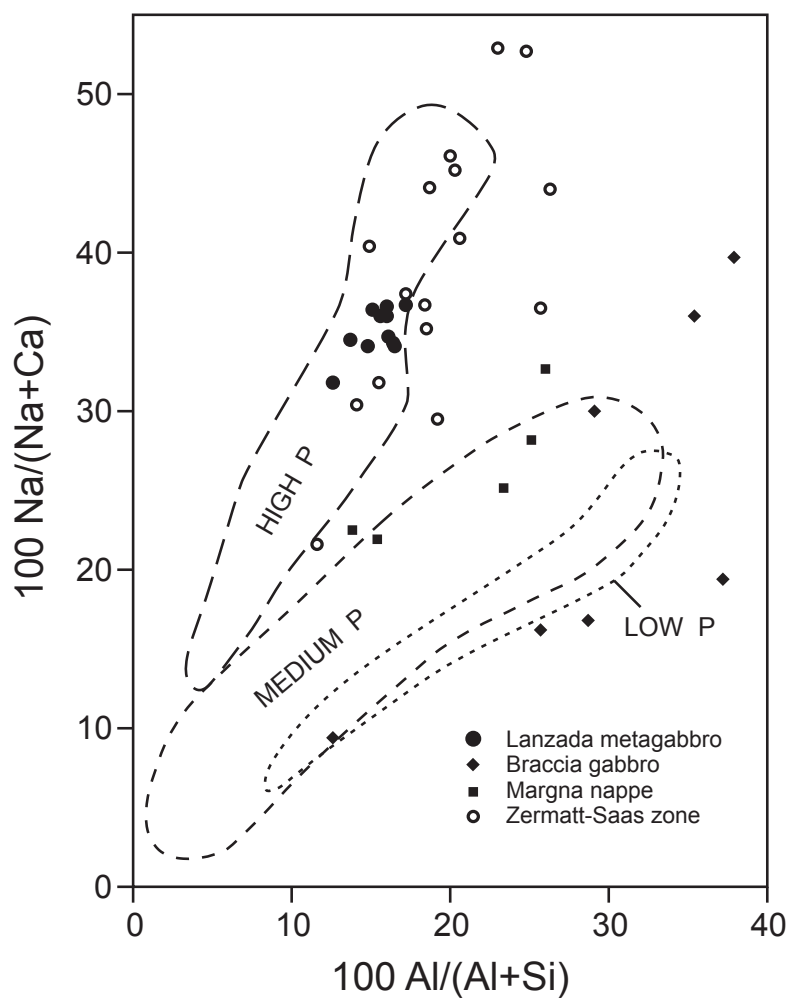


Figure 6

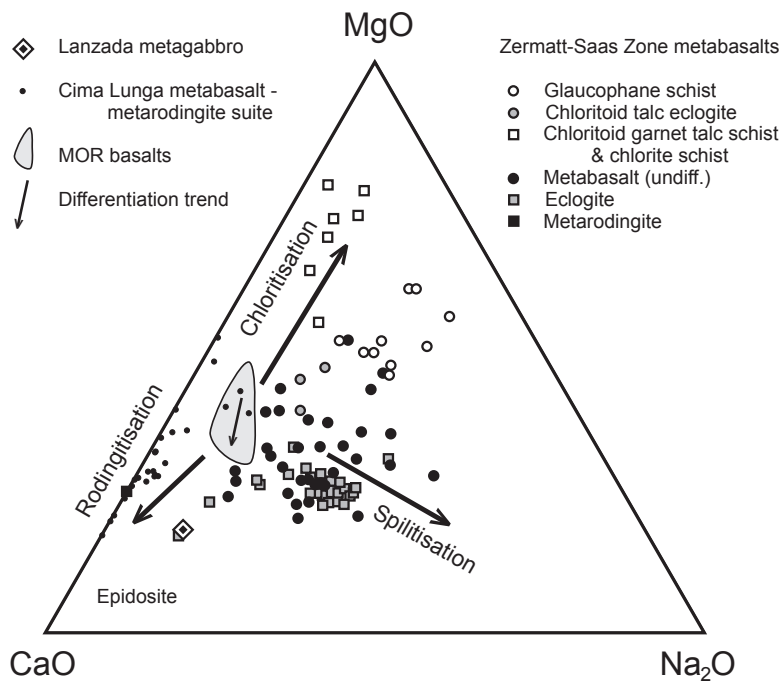


Figure 7

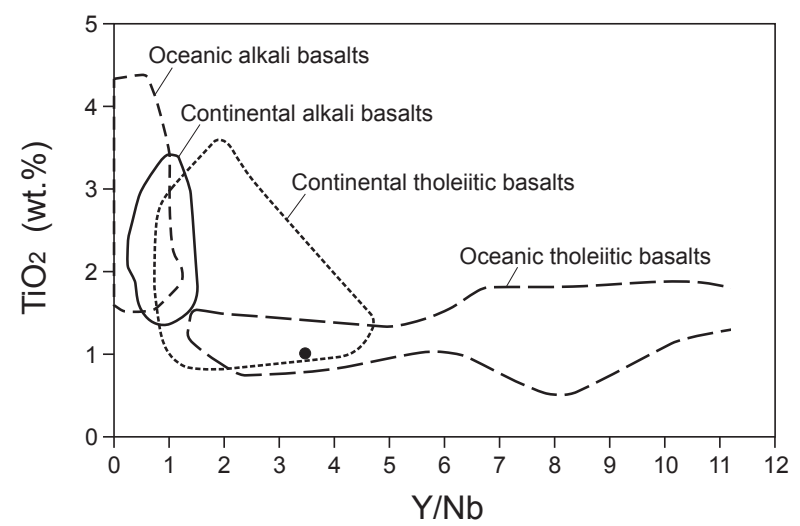


Figure 8

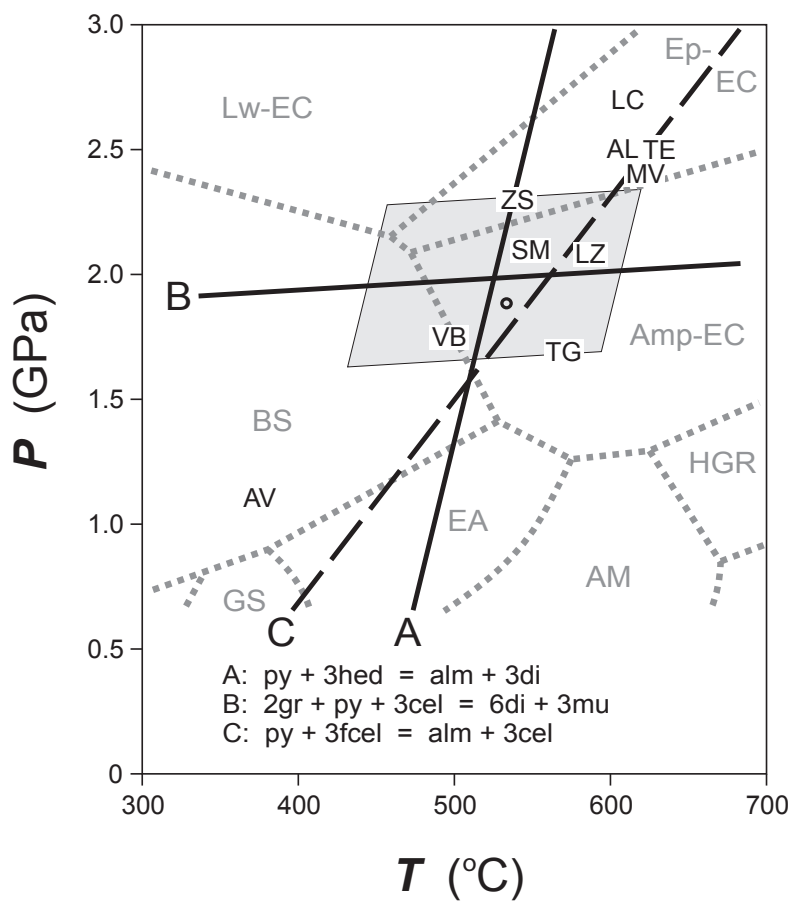




\begin{tabular}{|c|c|c|c|c|c|c|c|c|c|c|c|c|c|c|c|c|c|}
\hline & Garnet & Garnet & Garnet & Garnet & Omphacite & Omphacite & Omphacite & Omphacite & Epidote & Epidote & Epidote & Phengite & Phengite & Titanite & Hornblende & Hornblende & Albite \\
\hline & 1 & 2 & 3 & 4 & 1 & 2 & 3 & 4 & 1 & 2 & 3 & 1 & 2 & 1 & 1 & 2 & 1 \\
\hline & core & intermed. & near rim & $\begin{array}{l}\text { rim } \\
\text { cont. } C p x\end{array}$ & $\begin{array}{c}\text { core } \\
\text { Cpx agg. }\end{array}$ & $\begin{array}{c}\text { core } \\
\text { near Grt }\end{array}$ & $\begin{array}{c}\text { core } \\
\text { cont. Ep }\end{array}$ & $\begin{array}{c}\text { rim } \\
\text { cont. Grt }\end{array}$ & $\begin{array}{c}\text { core } \\
\text { dist. } \mathrm{Cpx}\end{array}$ & $\begin{array}{l}\text { rim } \\
\text { dist. } C p x\end{array}$ & $\begin{array}{l}\text { rim } \\
\text { cont. Grt }\end{array}$ & core & core & $\begin{array}{c}\text { small } \\
\text { cont. Cpx }\end{array}$ & core & $\begin{array}{c}\text { rim } \\
\text { cont. Cpx }\end{array}$ & poik \\
\hline \multicolumn{18}{|l|}{ Oxides } \\
\hline $\mathrm{SiO} 2$ & 37.20 & 37.50 & 37.66 & 37.63 & 54.71 & 55.65 & 55.06 & 55.55 & 38.66 & 38.29 & 36.94 & 49.50 & 49.49 & 30.34 & 49.18 & 48.93 & 67.87 \\
\hline $\mathrm{TiO} 2$ & 0.16 & 0.11 & 0.08 & 0.07 & 0.24 & 0.06 & 0.07 & 0.04 & 0.13 & 0.13 & 0.11 & 0.35 & 0.41 & 38.60 & 0.20 & 0.20 & 0.00 \\
\hline Al2O3 & 21.14 & 21.05 & 21.35 & 21.63 & 6.86 & 10.95 & 10.31 & 10.80 & 29.35 & 27.00 & 22.19 & 29.19 & 28.93 & 1.30 & 7.72 & 8.13 & 20.11 \\
\hline $\mathrm{Cr} 2 \mathrm{O} 3$ & 0.03 & 0.02 & 0.02 & 0.01 & 0.00 & 0.02 & 0.04 & 0.02 & 0.03 & 0.02 & 0.03 & 0.01 & 0.00 & 0.02 & 0.01 & 0.03 & 0.00 \\
\hline $\mathrm{Fe} 2 \mathrm{O} 3$ & - & - & - & - & 2.26 & 3.59 & 4.60 & 4.82 & 5.87 & 8.59 & 15.08 & 0.00 & 0.00 & - & 4.25 & 4.55 & 0.10 \\
\hline $\mathrm{FeO}$ & 27.77 & 27.64 & 26.18 & 25.18 & 4.23 & 4.18 & 3.92 & 3.16 & - & - & - & 3.12 & 3.18 & 0.32 & 8.80 & 9.03 & - \\
\hline $\mathrm{MnO}$ & 2.01 & 1.89 & 1.06 & 1.51 & 0.25 & 0.31 & 0.32 & 0.25 & 0.05 & 0.20 & 0.37 & 0.05 & 0.02 & 0.07 & 0.45 & 0.46 & 0.00 \\
\hline $\mathrm{MgO}$ & 1.16 & 1.27 & 1.70 & 1.69 & 10.10 & 6.34 & 6.25 & 6.46 & 0.05 & 0.04 & 0.00 & 3.26 & 3.23 & 0.01 & 13.44 & 13.11 & 0.00 \\
\hline $\mathrm{CaO}$ & 10.53 & 10.82 & 12.18 & 12.84 & 17.01 & 11.31 & 11.42 & 10.98 & 23.88 & 23.62 & 23.09 & 0.04 & 0.03 & 28.37 & 9.52 & 9.66 & 0.29 \\
\hline $\mathrm{Na} 2 \mathrm{O}$ & 0.00 & 0.00 & 0.00 & 0.00 & 4.61 & 7.83 & 7.74 & 8.08 & 0.00 & 0.00 & 0.00 & 0.51 & 0.57 & 0.01 & 2.96 & 2.79 & 11.46 \\
\hline K2O & 0.00 & 0.00 & 0.00 & 0.00 & 0.00 & 0.00 & 0.00 & 0.00 & 0.00 & 0.00 & 0.01 & 9.97 & 9.89 & 0.00 & 0.36 & 0.43 & 0.04 \\
\hline Total & 100.00 & 100.30 & 100.23 & 100.57 & 100.26 & 100.24 & 99.73 & 100.17 & 98.02 & 97.89 & 97.82 & 95.97 & 95.74 & 99.04 & 96.88 & 97.30 & 99.86 \\
\hline Formula & $12(0)$ & $12(0)$ & $12(0)$ & $12(0)$ & $6(0)$ & $6(0)$ & $6(0)$ & $6(0)$ & $12.5(\mathrm{O})$ & $12.5(0)$ & $12.5(\mathrm{O})$ & $11(0)$ & $11(0)$ & $5(0)$ & $23(0)$ & $23(0)$ & $8(0)$ \\
\hline $\mathrm{Si}$ & 2.976 & 2.988 & 2.982 & 2.966 & 1.978 & 1.991 & 1.987 & 1.986 & 2.987 & 2.996 & 2.971 & 3.289 & 3.297 & 0.999 & 7.151 & 7.100 & 2.969 \\
\hline $\mathrm{Ti}$ & 0.009 & 0.006 & 0.005 & 0.004 & 0.006 & 0.002 & 0.002 & 0.001 & 0.008 & 0.008 & 0.007 & 0.017 & 0.020 & 0.956 & 0.022 & 0.022 & 0.000 \\
\hline Al & 1.994 & 1.977 & 1.992 & 2.009 & 0.292 & 0.462 & 0.439 & 0.455 & 2.673 & 2.490 & 2.104 & 2.286 & 2.271 & 0.050 & 1.323 & 1.391 & 1.037 \\
\hline $\mathrm{Cr}$ & 0.002 & 0.001 & 0.001 & 0.001 & 0.000 & 0.001 & 0.001 & 0.001 & 0.002 & 0.001 & 0.002 & 0.001 & 0.000 & 0.000 & 0.001 & 0.003 & 0.000 \\
\hline $\mathrm{Fe} 3+$ & - & - & - & - & 0.061 & 0.097 & 0.125 & 0.130 & 0.341 & 0.506 & 0.913 & 0.000 & 0.000 & - & 0.465 & 0.497 & 0.003 \\
\hline $\mathrm{Fe} 2+$ & 1.858 & 1.842 & 1.733 & 1.660 & 0.128 & 0.125 & 0.118 & 0.095 & - & - & - & 0.173 & 0.177 & 0.009 & 1.070 & 1.096 & - \\
\hline $\mathrm{Mn}$ & 0.136 & 0.128 & 0.071 & 0.101 & 0.008 & 0.009 & 0.010 & 0.008 & 0.003 & 0.013 & 0.025 & 0.003 & 0.001 & 0.002 & 0.055 & 0.056 & 0.000 \\
\hline $\mathrm{Mg}$ & 0.139 & 0.151 & 0.201 & 0.199 & 0.544 & 0.338 & 0.336 & 0.344 & 0.006 & 0.005 & 0.000 & 0.322 & 0.321 & 0.000 & 2.913 & 2.835 & 0.000 \\
\hline $\mathrm{Ca}$ & 0.902 & 0.924 & 1.033 & 1.084 & 0.659 & 0.433 & 0.441 & 0.421 & 1.977 & 1.980 & 1.990 & 0.003 & 0.002 & 1.001 & 1.482 & 1.501 & 0.014 \\
\hline $\mathrm{Na}$ & 0.00 & 0.00 & 0.00 & 0.00 & 0.323 & 0.543 & 0.541 & 0.560 & 0.000 & 0.000 & 0.000 & 0.065 & 0.073 & 0.001 & 0.833 & 0.784 & 0.972 \\
\hline $\mathrm{K}$ & 0.00 & 0.00 & 0.00 & 0.00 & 0.000 & 0.000 & 0.000 & 0.000 & 0.000 & 0.000 & 0.001 & 0.845 & 0.841 & 0.000 & 0.067 & 0.080 & 0.002 \\
\hline Total & 8.017 & 8.017 & 8.017 & 8.025 & 4.000 & 4.000 & 4.000 & 4.000 & 7.997 & 7.999 & 8.013 & 7.005 & 7.004 & 3.019 & 15.382 & 15.365 & 4.998 \\
\hline $\mathrm{Mg} /(\mathrm{Mg}+\mathrm{Fe} 2)$ & 0.069 & 0.076 & 0.104 & 0.107 & 0.810 & 0.730 & 0.740 & 0.784 & - & - & - & 0.650 & 0.644 & - & 0.731 & 0.721 & - \\
\hline
\end{tabular}




\begin{tabular}{|c|c|c|c|}
\hline Major oxides & $\begin{array}{c}\text { Weight \% } \\
\text { oxides }\end{array}$ & $\begin{array}{c}\text { Weight \% } \\
\text { oxides }\end{array}$ & $\begin{array}{c}\text { Weight \% } \\
\text { oxides }\end{array}$ \\
\hline & $\begin{array}{c}\text { Lanzada } \\
\text { metagabbro } \\
(X R F)\end{array}$ & $\begin{array}{c}\text { Lanzada } \\
\text { metagabbro } \\
\text { (anhydrous } \\
\text { normalised) }\end{array}$ & $\begin{array}{c}\text { Average of } \\
1317 \text { gabbros } \\
\text { (anhydrous } \\
\text { normalised) } \\
\text { \& std. deviations } \\
\text { (LeMaitre, 1976) }\end{array}$ \\
\hline $\mathrm{SiO} 2$ & 45.24 & 46.24 & $51.06 \pm 4.56$ \\
\hline $\mathrm{TiO} 2$ & 1.03 & 1.05 & $1.17 \pm 1.00$ \\
\hline $\mathrm{Al} 2 \mathrm{O} 3$ & 14.57 & 14.90 & $15.91 \pm 3.66$ \\
\hline $\mathrm{Fe} 2 \mathrm{O} 3$ & 11.13 & 6.13 & $3.10 \pm 2.15$ \\
\hline $\mathrm{FeO}$ & - & 4.72 & $7.76 \pm 3.06$ \\
\hline $\mathrm{MnO}$ & 0.48 & 0.49 & - \\
\hline $\mathrm{MgO}$ & 4.57 & 4.67 & $7.68 \pm 3.48$ \\
\hline $\mathrm{CaO}$ & 17.74 & 18.13 & $9.88 \pm 2.78$ \\
\hline $\mathrm{Na} 2 \mathrm{O}$ & 3.00 & 3.07 & $2.48 \pm 1.17$ \\
\hline $\mathrm{K} 2 \mathrm{O}$ & 0.29 & 0.30 & $0.96 \pm 0.85$ \\
\hline $\mathrm{P} 2 \mathrm{O} 5$ & 0.28 & 0.28 & - \\
\hline $\mathrm{SO} 3$ & 0.02 & 0.02 & - \\
\hline $\mathrm{H}_{2} \mathrm{O}$ & 0.68 & - & - \\
\hline Total & 99.04 & 100.00 & 100.00 \\
\hline
\end{tabular}

Trace elements (ppm): Lanzada metagabbro

$\begin{array}{cccc}\mathrm{Sc} & 7.8 & \mathrm{Sn} & 8.6 \\ \mathrm{~V} & 153.0 & \mathrm{Sb} & \mathrm{bd} \\ \mathrm{Cr} & 274.2 & \mathrm{Te} & 27.0 \\ \mathrm{Co} & 66.7 & \mathrm{I} & \mathrm{bd} \\ \mathrm{Ni} & 185.5 & \mathrm{Cs} & 4.6 \\ \mathrm{Cu} & 60.6 & \mathrm{Ba} & 54.9 \\ \mathrm{Zn} & 77.5 & \mathrm{La} & 55.0 \\ \mathrm{Ga} & 22.6 & \mathrm{Ce} & 103.1 \\ \mathrm{Ge} & 2.9 & \mathrm{Nd} & 41.1 \\ \mathrm{As} & 5.7 & \mathrm{Sm} & 8.8 \\ \mathrm{Se} & \mathrm{bd} & \mathrm{Yb} & \mathrm{bd} \\ \mathrm{Br} & \mathrm{bd} & \mathrm{Hf} & 6.9 \\ \mathrm{Rb} & 7.7 & \mathrm{Ta} & \mathrm{bd} \\ \mathrm{Sr} & 489.3 & \mathrm{Hg} & \mathrm{bd} \\ \mathrm{Y} & 45.6 & \mathrm{Tl} & \mathrm{bd} \\ \mathrm{Zr} & 139.9 & \mathrm{~Pb} & 25.4 \\ \mathrm{Nb} & 13.0 & \mathrm{Bi} & \mathrm{bd} \\ \mathrm{Mo} & 0.9 & \mathrm{Th} & 14.5 \\ \mathrm{Ag} & \mathrm{bd} & \mathrm{U} & 5.3 \\ \mathrm{Cd} & \mathrm{bd} & & \end{array}$

CIPW Weight Norm: Lanzada metagabbro

\begin{tabular}{|c|c|c|c|}
\hline Plagioclase & 39.77 & Diopside & 30.32 \\
\hline$A n$ & 25.53 & Di & 25.65 \\
\hline$A b$ & 14.24 & $H d$ & 4.67 \\
\hline Orthoclase & 1.77 & Wollastonite & 10.00 \\
\hline Nepheline & 6.57 & Ilmenite & 1.99 \\
\hline $\mathrm{Na} 2 \mathrm{SO} 4$ & 0.04 & Magnetite & 8.89 \\
\hline Apatite & 0.65 & & \\
\hline
\end{tabular}


Supplementary Material
Click here to download Supplementary Material: Droop \& Chavrit text May 2014 highlighted.doc

Supplementary Material
Click here to download Supplementary Material: Droop \& Chavrit text May 2014 highlighted.doc 